Policy Research Working Paper 7732

\title{
Who Benefited from Burundi's Demobilization Program?
}

Olivia D'Aoust

Olivier Sterck

Philip Verwimp 
Policy Research Working Paper 7732

\begin{abstract}
This paper assesses the impact of the demobilization, reinsertion and reintegration program in post-war Burundi. Two major rebel groups benefited from cash and in-kind transfers, the CNDD-FDD from 2004, and the FNL from 2010. A panel data of households collected in 2006 and 2010 is combined with official records from the National Commission for Demobilization, Reinsertion and Reintegration. Regression analysis shows that the cash payments received by FNL demobilized households had a positive impact on consumption, nonfood spending and investments. The
\end{abstract}

program also generated positive spillovers in the villages where FNL combatants returned. Ex-combatants indeed spent a large part of their allowance on consumption goods and clothing, thereby generating a short-run economic boom in villages. However, the long-run evolution of consumption indicators is negative for CNDD-FDD households, as well as for villages where CNDD-FDD combatants returned, suggesting that the direct impact and the spillovers of the program vanished in the long run.

This paper is a product of the Operations and Strategy Team, Development Economics Vice Presidency. It is part of a larger effort by the World Bank to provide open access to its research and make a contribution to development policy discussions around the world. Policy Research Working Papers are also posted on the Web at http://econ.worldbank.org. The authors may be contacted at olivier.sterck@economics.ox.ac.uk.

The Policy Research Working Paper Series disseminates the findings of work in progress to encourage the exchange of ideas about development issues. An objective of the series is to get the findings out quickly, even if the presentations are less than fully polished. The papers carry the names of the authors and should be cited accordingly. The findings, interpretations, and conclusions expressed in this paper are entirely those of the authors. They do not necessarily represent the views of the International Bank for Reconstruction and Development/World Bank and its affiliated organizations, or those of the Executive Directors of the World Bank or the governments they represent. 


\title{
Who benefited from Burundi's Demobilization Program?'
}

\author{
Olivia D'Aoust, Olivier Sterck, Philip Verwimp
}

Keyword: Conflict; Burundi; Disarmament, Demobilization and Reintegration Program ; Cash Transfer; Spillovers

JEL Classification: D74, O12, I32, I38, N47

\footnotetext{
${ }^{1}$ Olivia D'Aoust is an economist at the World Bank; the paper was written while she was a doctoral candidate at the European Centre for Advanced Research in Economics and Statistics, Université libre de Bruxelles (ECARES, ULB); her email address is odaoust@worldbank.org. Olivier Sterck (corresponding author) is Research Fellow at the Centre for the Study of African Economies (CSAE) at the University of Oxford; his email address is olivier.sterck@economics.ox.ac.uk. Philip Verwimp is Associate Professor of development economics at ECARES, ULB, Belgium; his email address is philip.verwimp@ulb.ac.be. Olivia D'Aoust and Philip Verwimp acknowledge financial support from the Alain and Marie Philippson Chair and the Fonds National de la Recherche Scientifique (FNRS). Olivier Sterck would like to thank the ARC project 09/14-018 on "sustainability" (French speaking community of Belgium) for its financial support. The fieldwork for this study was funded by the MICROCON project (EU 6th Framework). The authors would also like to thank Julien Camus and our team of survey interviewers and supervisors for excellent research assistance. We also thank the Demobilisation and Reintegration Unit in the Government of Burundi for their cooperation. We are grateful to Bram De Rock, Antonio Estache, James Fenske, William Parienté, Jean Philippe Platteau, Gérard Roland and to participants in the $2011 \mathrm{HiCN}$ Annual Workshop, the Centre Emile Bernheim Seminar at ULB, the 2011 CSAE Annual Conference in Oxford, the 2012 ENTER Jamboree and the Summer School in Development Economics co-organized by the Italian Development Economist Association. The article has also benefited substantially from the insights, comments and patience of three anonymous referees and the journal editor. Any opinions, findings, and recommendations expressed in this paper are those of the authors only.
} 
Disarmament, demobilization and reintegration (DDR) programs are an essential component of most peace-building programs. The primary goal of such programs is to secure shortrun stability in postconflict countries, clearing the way for structural reforms (Pugel, 2009). Over the last two decades, such programs have been implemented in more than 30 countries. More than 2.5 million people have benefited from some form of demobilization worldwide since 1989, with an average annual cost of more than \$US 600 million (Muggah, 2009).

Despite their high costs and a seemingly widespread belief in their extreme importance for stability in postconflict countries, empirical evidence on the effectiveness of DDR programs remains scarce. Comparing soldiers who voluntarily participated in one of these programs to those who did not, Humphreys and Weinstein (2007) find little evidence that the DDR program in Sierra Leone facilitated demobilization and social reintegration. By exploiting a disruption in the DDR transfers in Burundi, Gilligan et al (2013) found that in-kind allocations led to a decrease in poverty and improved livelihoods among beneficiary ex-combatants. While they concluded that the program was successful in terms of economic reintegration, they found no effect on ex-combatants' overall satisfaction and attitudes towards norms.

Building on these insightful studies, we study the impact of the Burundian DDR program and extend the literature on DDR assessments in three ways: (i) by capturing the effect of potential spillovers to civilian households; (ii) by disentangling the short-run impacts from long-run dynamics; and (iii) by distinguishing between DDR phases. The DDR program in Burundi targeted 33,500 ex-combatants at the end of the 1993-2009 civil war. The program was conducted in two waves. The first wave started in December 2004 with the demobilization of the major Hutu rebel group, the CNDD-FDD ${ }^{1}$ and the demobilization of a few other minor factions. The second wave started in 2009 with the demobilization of the second larger Hutu rebel group, the Palipehutu-FNL ${ }^{2}$ We denote by CNDD+ the beneficiaries of the first wave of demobilization and by FNL the beneficiaries of the second wave. The program featured two subsequent components. Through the reinsertion component, demobilized combatants received a cash allowance of at least US\$ 515 distributed over 18 months. Demobilized combatants then benefited from a reintegration grant, worth US\$ 545 and distributed in-kind.

According to economic theory, the impact of cash and in-kind transfers to demobilized combatants depends on whether they face financial, social, or behavioral constraints which are relaxed following the transfers (Fafchamps et al, 2011; Blattman et al, 2014). If agents do not face such constraints, they should already produce at their efficient scale, and it follows that DDR allowances should be expected to be consumed or saved for future consumption. Greater demand should then generate a temporary economic boom at the local level. The resulting increases in

\footnotetext{
${ }^{1}$ Conseil National pour la Défense de la Démocratie - Forces de Défense de la Démocratie.

${ }^{2}$ Palipehutu - Forces Nationales de Libération.
} 
price ${ }^{3}$ and turnover should benefit local vendors, but disadvantage buyers (Cunha et al, 2011; D'Aoust et al, 2013). If, however, there exist financial, social or behavioral constraints that are relieved by demobilization transfers, demobilization allowances would be expected to be invested in productive assets. In this case, the impact on consumption and assets of beneficiary households should be positive and long-lasting, but the magnitude of the consumption increase should be rather small (Gertler et al, 2012). Spillovers on nonbeneficiaries at the community level are expected to be marginal. Examining which of the consumption or investment scenarios prevails is an empirical question, which we tackle in the empirical analysis.

We use a household panel dataset to capture the direct and indirect effect of the DDR program on beneficiary and nonbeneficiary households. The first wave of the panel was collected in 2006, while the reintegration phase of the demobilization of CNDD+ combatants was taking place. This wave is representative at the provincial level. The second wave was collected in 2010 , in the midst of the reinsertion phase for FNL combatants, and about five years after the demobilization of CNDD+ combatants. The timeline below summarizes graphically the various components of our assessment (figure 1).

Figure 1: Timeline

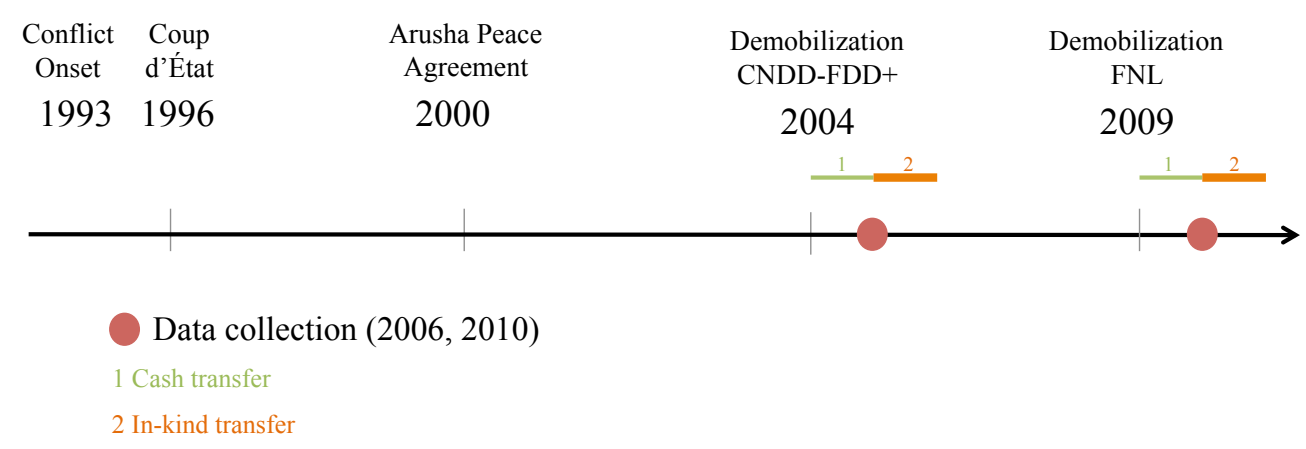

Our identification strategy exploits several key facts: (i) not all households hosted excombatants; (ii) not all households with ex-combatants benefited from allowances; (iii) the waves of the demobilization program took place before and in between the two survey rounds of the panel; and (iv) some communities in the panel had ex-combatants among their populations whereas other communities did not. Our outcomes of interest include indicators of consumption, nonfood spending, livestock, and prices. We call all households hosting an ex-combatant returnees, and we call the subset of returnees which received demobilization allowances demobilized. In order to measure the short-run impact of reinsertion allowances on beneficiaries,

\footnotetext{
${ }^{3}$ This holds only if the degree of openness and competition in the local economy is low, as is the case in rural Burundi.
} 
we compare the outcomes of FNL demobilized households and FNL returnee households that did not benefit from reinsertion allowances. In the same vein, we measure the long-run evolution of the impact of program on CNDD+ by comparing outcomes of the CNDD+ demobilized households and CNDD+ returnee households that did not benefit from the DDR program. We measure the short-run (resp. long-run) spillovers of the program on nonbeneficiaries by studying how households' outcomes are affected by the density of demobilized FNL (resp. CNDD+) in their community.

We find that demobilization grants had a positive and significant impact on economic outcomes of FNL beneficiaries in the short run. Importantly, we also identify the presence of positive spillovers on nonbeneficiary households in the short run. This result is encouraging as it shows that reinsertion grants benefited the local economy, which may have increased local acceptance of ex-rebels. However, our analysis identifies a negative evolution of consumption and nonfood spending for CNDD+ ex-combatants. Similarly, we find that the density of demobilized combatants who benefited from the first wave of the DDR program is negatively correlated with outcomes of interest.

These results show that the consumption scenario prevailed in Burundi. When they returned home, demobilized FNLs spent a large part of their allowances on their immediate needs such as food and other basic spending. The demand for locally produced goods rose, which generated a short-run economic boom in host villages. Consistent with this narrative, we find that prices increased in the local market. The results on CNDD+ demobilized households are also consistent with the consumption scenario. Like demobilized FNL households in 2010, we argue that CNDD+ households are likely to have experienced a consumption boom when they benefited from reinsertion allowances as of 2004. Verwimp and Bundervoet (2009) found that the consumption of CNDD+ ex-combatants' households increased by 34\% between 1998 and 2007 compared to civilian households. Qualitative evidence also confirms that CNDD+ ex-combatants spent a large share of their grants in nonproductive ways (Uvin, 2007). Under the assumption that CNDD+ households experienced a consumption boom similar to FNL households when they benefited from reinsertion allowances, our findings show that CNDD+ households were not able to maintain a high level of consumption after the exhaustion of their demobilization money.

Importantly, Gilligan et al (2013) also assessed the impacts of the Burundian DDR and focused on the short-run impact of the reintegration phase for CNDD+ combatants. Their analysis exploited an exogenous bureaucratic failure in the implementation of the program, which resulted in delays of the distribution of in-kind reintegration allowances for demobilized combatants living in certain provinces. Our analysis complements the study of Gilligan et al (2013) by using panel data methods to assess the impact of the reinsertion phase on FNL combatants, by studying long-run dynamics for CNDD+ combatants, and by capturing the impact of 
spillovers on civilian households.

The paper is organized as follows. Section 2 provides details on Burundian DDR. In section 3, we present a theoretical framework describing the expected effects of demobilization allowances. In the fourth section, we describe the data and introduce the identification strategy. Results are presented in section 5 and interpreted in section 6 . The last section concludes.

\section{Background of the DDR program in Burundi}

The 1993-2009 conflict in Burundi was driven by years of ethnic discrimination (Vandeginste, 2009). A few years after independence in July 1962, the Tutsi elite established a military dictatorship. Tensions between the Hutu majority and the Tutsi authoritarian government regularly triggered violent clashes. In 1988, Tutsi President Pierre Buyoya launched a process of political liberalization, establishing a government of national unity and organizing elections in 1993. In October 1993, four months after his election, the newly elected Hutu President Ndadaye was assassinated. This event set off a decade of civil war between Hutu rebel groups and the Tutsi-led Burundian army.

In 2000, the Arusha Peace Agreement laid the foundations for a peace process and a new constitution based on power-sharing and de-ethnicized political competition. Two Hutu rebel groups, the CNDD-FDD and the Palipehutu-FNL, refused to sign the peace agreement. The ethnic conflict turned into a civil war opposing the transitional government and the two Hutu rebel groups. In 2003, the CNDD-FDD agreed to lay down its weapons and its leaders were given positions in the government, in the national assembly and in the administration. Combatants from the national army (FAB) and from the CNDD-FDD were selected to join the national police and the new national army (The Forces de Défense de la Nation-FDN). Selection criteria were based on stated preferences, age, health status, and experience. Those who were not selected, about 23,000 combatants from CNDD-FDD and FAB, were assigned to the disarmament, demobilization, and reinsertion (DDR) program. The DDR program was officially launched in December 2004.

In 2009, the Palipehutu-FNL rebels in turn gave up their arms and the FNL became a political party, with 33 minor posts given to the FNL leadership. Of the 20,000 Palipehutu-FNL members. 3 3,500 were reintegrated in the Burundian army and 6,500 benefited from the DDR program.

The program was coordinated by the National Commission for Demobilization, Reinsertion and Reintegration: $\left[5^{5}\right.$ under the supervision of the World Bank. The progam was organized in

\footnotetext{
${ }^{4}$ This number was inflated by the FNL leadership. Knowing that the CNDD-FDD had received the DDR and expecting to benefit from such a program, many people did join the rebel group right before the agreement was signed.

${ }^{5}$ Commission Nationale de Démobilisation, Réinsertion and Réintégration (CNDRR)
} 
three phases: the demobilization, the reinsertion and the reintegration. The demobilization phase started with disarmament, followed by the transfer of ex-combatants to a demobilization center. Ex-combatants spent eight days in the center, attending training on economic strategies and opportunities, HIV/AIDS, civic responsibility, as well as peace and reconciliation.

As part of the reinsertion phase, demobilized combatants received a cash allowance worth 18-month salary, paid in four installments over a period of eighteen months. Demobilized combatants received the first reinsertion payment when leaving the demobilization center. Called the Transitional Subsistence Allowance (TSA) by the World Bank, the reinsertion money was dedicated to "enable the ex-combatants to return to their community and to sustain themselves and their families for a limited period following demobilization" (The World Bank Group, 2004). The total amount of the cash allowance increased with military rank, starting from a minimum of FBU 566,000 (US\$ 515). 6 The average benefit amounted to FBU 644,000 per demobilized combatant (US\$ 586). Data from our survey in 2010 shows that civilian households consumed on average about FBU 190,000 (US\$ 173) per adult equivalent per year, which is about one third of the minimum cash allocation to FNL rebels.

Finally, the reintegration phase consisted of a one-off in-kind transfer worth FBU 600,000 (US\$ 545). The ex-combatants could choose from a range of options, including vocational training, support for agro-pastoral activity, and start-up material for a small business or a construction project. This phase was launched in September 2006 for the CNDD+.7 Of the 23,000 CNDD+ beneficiaries, $85 \%$ had received the reintegration support by December 2008. This phase was just starting for the FNL ex-combatants at the time of our 2010 survey.

Some rebels had ties with the factions, but did not benefit from the DDR program. A list of criteria was established in order to assess the military aptitudes of candidates, defining whether rebels were eligible or not for the DDR program. The DDR program also included the disarmament and the dismantling of militias. These were formed by people helping the factions, notably in terms of logistics. These people were called "Gardiens de la Paix" (GdP) if they belonged to the FAB, "Militants Combatants" (MC) if they were part of the CNDD-FDD and "Adultes Associés" (AA) if they supported the FNL. 20,000 GdP, 10,000 MC and 11,000 AA benefited from the program. They received FBU 100,000 (US\$ 91) as compensation.

\section{Theoretical Framework}

The DDR program in Burundi was a social transfer program combining cash and in-kind benefits. We aim to assess its short- and long-run impacts, and to disentangle its direct impact

\footnotetext{
${ }^{6}$ All US\$ equivalents are expressed in 2010 US\$. US\$ 1 was worth 1,100 Burundian francs in 2010.

${ }^{7}$ This phase did not start before March 2008 in the central provinces (Gilligan et al, 2013); the provinces included in the present analysis were not affected by this disruption.
} 
on beneficiaries from its indirect impact on civilians. In this section, we rely on the theoretical and empirical literature on cash and in-kind transfers to predict the direction and the size of these effects.

Standard models of investment predict that agents produce at their efficient scale if financial markets function well (Blattman et al, 2014; Fafchamps et al, 2011). With well-functioning financial markets, cash and in-kind allowances are therefore not used to expand production, but rather to increase current consumption and future consumption through savings. Consumption smoothing depends on individuals' discount rate: individuals with strong preference for the present, that is, a high discount rate, will save less. Cash and in-kind transfers have therefore no impact on capital and profit in the long run in this case.

These predictions change if agents face financial, social or behavioral constraints which are relaxed as a result of the cash and in-kind transfers. For example, businesses facing liquidity or credit constraints should grow rapidly when given additional capital (Besley, 1995; Sadoulet et al, 2001). Whether this capital is provided in cash or in-kind should not affect the level of investment as long as people make decisions regarding asset accumulation in an integrated manner, that is, if consumption, profit, capital and saving are regarded as fungible (Fafchamps et al, 2011). However, cash and in-kind allowances can have systematically different effects if asset integration fails, for example because of self-control issues (Banerjee and Mullainathan, 2010), intra-household allocation inefficiencies (Udry, 1996) or redistributive pressures (Platteau, 2000).

A large empirical literature documents the positive impacts of cash transfers on consumption (see, e.g., Duflo (2003); Hoddinott and Skoufias (2004); Fafchamps et al (2011); Cunha (2014); Blattman et al (2014); Haushofer and Shapiro (2014); Hidrobo et al (2014)). Studies on the dynamics of social transfers and consumption show that consumption tends to peak just after the payment (Stephens Jr, 2003; Shapiro, 2005; Stephens, 2006; Mastrobuoni and Weinberg, 2009). The empirical literature also documents that cash transfers can have a positive impact on assets (Haushofer and Shapiro, 2014; Blattman et al, 2014; de Mel et al, 2008). Investment in assets can in turn generate additional income and consumption, thereby generating a multiplier effect (Sadoulet et al, 2001; Gertler et al, 2012). The impact of transfers depends on the presence of conditionalities (Baird et al, 2011), on the timing and frequency of transfers (Stephens Jr, 2003, Haushofer and Shapiro, 2014), on self-control issues, and on the extent to which preferences are present-biased (Shapiro, 2005; Ozdenoren et al, 2012; Evans and Popova, 2014; Fafchamps et al, 2011).

Recently, several studies in development economics have identified large externalities of development programs on nonbeneficiaries. These studies conclude that the impact of interventions may be substantially underestimated if such spillovers are not considered. Nonbeneficiaries may be affected by the interventions through three main channels (Glennerster and 
Takavarasha, 2013). The first channel is physical. For example, untreated individuals can be positively affected by a treatment slowing the spread of a contagious epidemic (Miguel and Kremer, 2004). The second channel is informational or behavioral: programs can have an impact on the untreated through imitation and communication with treated peers (Kim et al, 1999, Bobonis and Finan, 2009). The third channel relates to market-wide effects. In our case, social transfer programs can generate externalities in village economies because the program's money immediately passes from recipient to nonbeneficiary households as the cash is used to purchase goods and services or to transfer money to peers. Resulting general equilibrium effects have been highlighted in research on agricultural growth multipliers (Block, 1999; Haggblade et al, 1991; Filipski et al, 2015) as well as in work on structural models of village economies (Kaboski and Townsend, 2011; Attanasio et al, 2012).

As local demand increases, local traders' revenue increases. Under general assumptions, prices of normal goods in the local market should then increase in the short run if the degree of openness and competition in the local economy is low (Cunha et al, 2011; D'Aoust et al, 2013). In the long run, prices should return to their equilibrium as local traders adapt to the increased demand and as excess money escapes the local economy for purchasing goods that are not produced locally (Cunha et al, 2011; D'Aoust et al, 2013). The short-run increase in price should further increase the profit of local traders, while being detrimental for buyers (Filipski et al, 2015). The price increase may be attenuated if cash allowances are partly invested in assets that increase productive capacity in villages. For goods that are imported locally and characterized by oligopolistic competition, prices could even decrease following the positive demand shock if local traders face fixed costs in a Bertrand competition model or if the demand shock causes more stores to sell the good, thereby increasing competition in a Cournot-Nash framework (Cunha et al, 2011; D'Aoust et al, 2013).

Few empirical studies have examined the price effects and the externalities of cash transfers on nonbeneficiaries. For example, using the data from Progresa in Mexico, Angelucci and De Giorgi (2009) and Barrientos and Sabatés-wheeler (2009) find that noneligible households in treatment areas show significantly higher levels of food consumption and asset holdings following the introduction of the conditional cash transfer program, compared to noneligible households in control areas. Studying the impact of the PAL program in Mexico, Cunha et al (2011) find that cash transfers in remote villages led to higher food prices, which in turn increased agricultural profits and household wealth. They also show theoretically and empirically that prices are lower following in-kind transfers, which affect supply whereas cash transfers affect demand.

This review of the literature shows that the impacts and externalities of the Burundian DDR are expected to depend on how ex-combatants used their allowances. The use of allowances ultimately depends on socio-economic constraints faced by beneficiaries and socio-economic 
conditions in the village economies. Figure 2 shows how ex-combatants from our sample reported spending their grant. It summarizes the self-reported information provided by 22 demobilized ex-combatants and $9 \mathrm{GdP} / \mathrm{MC} / \mathrm{AA}$ who were interviewed in 2010. Respondents could give a maximum of three figures..$^{8}$

In line with the literature, we observe that a large proportion of ex-combatants used a share of the money to buy consumption goods: $48 \%$ reported purchasing food and drinks, and $26 \%$ reported buying clothes. This consumption boom is expected to be short-lived, especially if the discount rate of ex-combatants is low and if saving opportunities are scarce. In the short run, the demand increase should induce a jump in prices. This change in prices should increase the sales of shopkeepers and farmers, who are therefore expected to benefit from the return of demobilized ex-rebels. Other households may suffer from inflation. However, the global effect on nonbeneficiaries is expected to be positive, as most households are involved in some kind of trading activity.

Figure 2: DDR Grants Spending by Ex-combatants

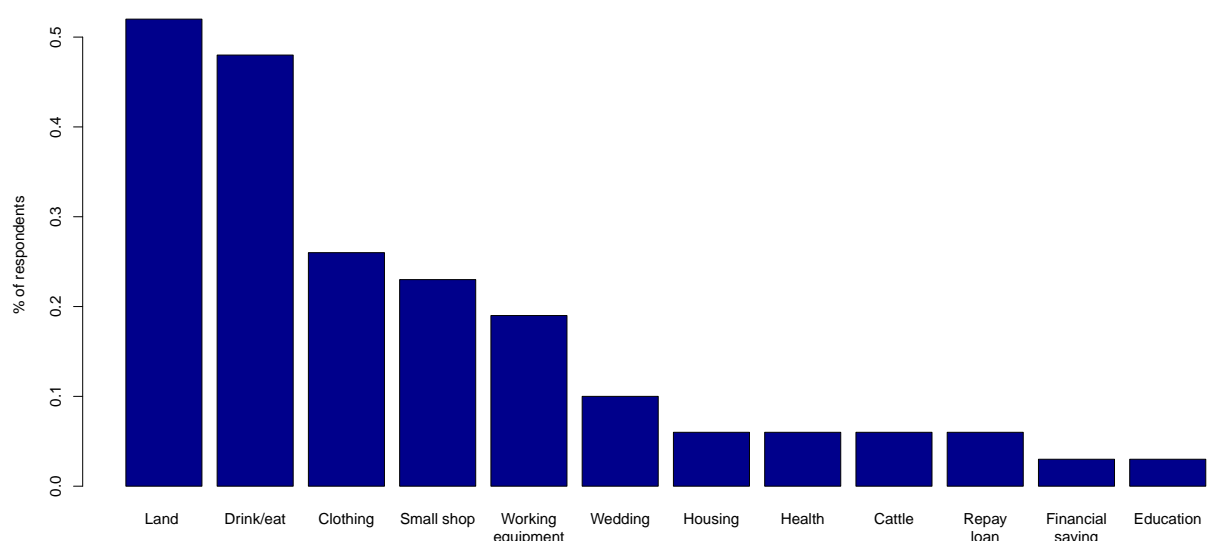

Source: Authors' analysis based on data described in the text.

Ex-combatants also invested part of their allowances in productive assets. More than $50 \%$ of ex-combatants reported investing part of the grant in a plot of land, $23 \%$ of them invested in a small shop, $19 \%$ in working equipment, and one ex-combatant reported buying a cow. The economic situation of ex-combatants who invested in productive assets is expected to improve in the short run and in the long run following their enhanced production capacity. The resulting long-run increase in consumption is expected to be marginal compared to the size of the

\footnotetext{
${ }^{8}$ In most households, they did not remember exactly how much they had spent for each category of expenses so figure 2 only shows the proportion of respondents that declared having spent part of their allowance in each category.
} 
immediate consumption boom following the distribution of reinsertion allowances. 9 As a corollary, the price effect and the externalities generated by investments of DDR money should be marginal except if investments were concentrated in specific domains. The in-kind allowances, which were distributed as part of the reintegration package, are likewise expected to have a positive but small impact on consumption in the long run.

In accordance with this line of reasoning, we propose to test the following hypotheses:

- Hypothesis 1. Reinsertion allowances received by demobilized combatants had a positive impact on the levels of consumption and investment of their household.

- Hypothesis 2. The short-run impacts on consumption of beneficiary households were short-lived. The impacts on investment lasted in the long run

- Hypothesis 3. Nonbeneficiaries were also indirectly affected by the program. This indirect impact depends on the main occupation of households.

- Hypothesis 4. Higher demand for normal goods induced a price increase in the short run.

By testing these hypotheses, we contribute not only to the scarce literature on the impact of demobilization programs, but also to the literature on the impact of cash and in-kind transfer programs on beneficiaries, nonbeneficiaries and prices.

\section{Empirical Analysis}

\subsection{The Data}

The empirical analysis draws on different types of data. The first dataset consists of a panel of households. The second dataset is a community questionnaire. The third dataset consists of administrative data from the National Commission for Demobilization, Reinsertion and Reintegration.

The Panel Dataset. The first dataset constitutes a two-round household survey undertaken in Burundi. The first round is a QUIBB/CWIQ survey that is representative at the provincial leve ${ }^{10}$ collected in February 2006. The survey was requested by the Ministry of Planning and designed by the World Bank. Data collection was coordinated by the University of Burundi. The CWIQ Survey Technology has been applied in different African countries for the purpose of generating standardized indicators of poverty and welfare. Developed by the World Bank

\footnotetext{
${ }^{9}$ For example, in their evaluation of Progresa in Mexico, Gertler et al (2012) estimated that for each peso transferred, households consumed 74 cents and invested the rest, increasing long-term consumption by only 1.6 cents.

10“Questionnaire des Indicateurs de Base du Bien-être" or "Core Welfare Indicator Questionnaire".
} 
in collaboration with other international agencies, it seeks to reduce the untimeliness of data and poor data quality with a less expensive alternative optimizing the sampling procedure and the structure of the questionnaire (Ajayi, 2006; Zoyem et al, 2008). Besides the core modules on household characteristics and consumption behavior, each country can implement additional modules according to its specificities. In the QUIBB for Burundi, questions about displacement and return were included. The sample consists of 6,700 households. The QUIBB sample is characterized by two-stage cluster sampling. In the first stage, 548 sous-collines ${ }^{11}$ were sampled and in the second stage, 15 households were sampled in each primary unit ${ }^{12}$ From the original data set, we applied a standard data cleaning process, where missing observations, data entry errors, potential measurement errors, distillation errors and outlier from unusual consumption were deleted.

The second round, undertaken by the authors in April 2010, only retained three provinces of the QUIBB sample: Bubanza, Bujumbura Rural, and Cibitoke, located in the North-West of the country. The choice of these provinces is justified by the concentration of ex-combatants in these three provinces in combination with high level of violence in the region over the last years, as well as by budgetary constraints. We traced 1284 households which were interviewed for the QUIBB survey in the three provinces of interest. A total of 1064 (or 83\%) households were found and interviewed in 85 collines $\sqrt[13]{3}$ We examine issues related to attrition more closely in section 3.2 .

In order to maximize the reliability of the data, we trained interviewers for a week. Interviews were conducted in Kirundi, the local language. After the training, interviewers were selected on the basis of an exam and simulated interviews. The questionnaire was then tested during a pilot study in a colline that was not included in our sample. We assigned teams of five interviewers, each including a team leader and at least two women. Each interviewer did two interviews per day on average. The questionnaires were then checked for accuracy and entered in a CS-PRO program by data entry agents. We checked the accuracy of entry ex-post, too.

Community Data. During the 2010 survey, enumerators also undertook a community survey in each colline. This survey included data on past violence, public services, and community initia-

\footnotetext{
${ }^{11}$ There are four administrative levels in Burundi: the province, the commune (translated "municipality"), the colline (translated "hill”) and the sous-colline (translated "sub-hills").

${ }^{12}$ The QUIBB survey used the same sampling strategy as the Multiple Indicator Cluster Survey (MICS), collected in September 2005 by UNICEF. The MICS survey mostly focuses on health and gender issues, and contains little useful information about economic outcomes. The sampling weights of the MICS survey will accounted for in the empirical analysis (results do not change without taking into account these sampling weights).

${ }^{13}$ There were three collines in which we could not trace households, all located in Bujumbura Rural. In two collines, the villagers reported not to know the households, either because they had migrated or were invented by 2005 interviewers. The remaining colline was not secure enough to conduct the survey.
} 
tives. The data on violent events is used as a control variable in our econometric model. We also use population data, based on the 2008 census, in order to scale the number of ex-combatants in each colline.

Official Demobilization Registers. The National Commission for Demobilization, Reinsertion, and Reintegration in Burundi provided us with registers of ex-combatants by colline and faction, along with their sex, age, military rank, colline of origin and of return, as well as the date of their demobilization. The registers contain precise information about each demobilized ex-combatant as well as the exact number of demobilized soldiers in each colline. The large variation in the number of demobilized ex-combatants per colline allow us to identify the spillovers of the DDR program in Burundi.

\subsection{Identification Strategy}

Our identification strategy is based on a lagged dependent variable model with province fixed effects. The lagged dependent variable model should be preferred to the difference-indifferences model when the assumption "that the most important omitted variables are timeinvariant doesn't seem plausible" (Angrist and Pischke, 2008). The particular histories of civilian and ex-combatants households motivate an estimation strategy that controls for lagged dependent variables directly and dispenses with households fixed effects. Furthermore, when autocorrelation of outcomes is low or when data is imprecisely measured, as is the case for many economic variables such as household incomes and expenditures (McKenzie, 2012), controlling for the lagged dependent variable is more powerful than either employing the differencein-differences estimator or the single difference estimator using only the follow-up data. Intuitively, "when the baseline data have little predictive power for future outcomes, it is inefficient to fully correct for baseline imbalances between treatment and control groups" (McKenzie, 2012). Because the coefficients of correlation correlation between our outcomes of interest in 2006 and in 2010 are low 14 we include the lagged dependent variable as a control variable in the regressions.

According to this in accordance with this approach, we propose to estimate the following equation:

$$
\begin{aligned}
\Delta \log Y_{i, 2010}= & \beta_{0}+\eta_{1} R_{i}^{C N D D+}+\beta_{1} R_{i}^{F N L}+\eta_{2} D_{i}^{C N D D+}+\beta_{2} D_{i}^{F N L} \\
& +\eta_{3} S_{i}^{C N D D+}+\beta_{3} S_{i}^{F N L}+\delta \log Y_{i, 2006}+\mathbf{X}_{i}^{\prime} \gamma_{i}+Z_{k}+\epsilon_{i}
\end{aligned}
$$

\footnotetext{
${ }^{14}$ The coefficient of correlation between the logarithm of total consumption per adult equivalent in 2006 and 2010 is 0.12 . For other dependent variables - the logarithm of consumption expenditures per AE, the logarithm of consumption from stocks per AE, the logarithm of nonfood expenditures and the logarithm of tropical livestock units - coefficients of correlation between 2006 and 2010 are equal to $0.19,0.10,0.18$ and 0.28 respectively.
} 
We consider six dependent variables. The first three economic outcomes are consumption aggregates that are constructed following the guidelines of Deaton and Zaidi (2002) (see appendix B.1 for details). The first indicator measures the total consumption per adult equivalent (AE) of 47 consumption goods. About two thirds of this aggregate is related to the consumption of cereals, fruits and vegetables. The other important food categories are beers and sodas (7.7\%), fish, meat, and eggs (7\%), condiments (3.3\%) and milk (3.3\%). The second dependent variable is the part of total consumption that was purchased over the 15 days preceding the survey. This variable is labeled consumption expenditures per adult equivalent. Similarly, the third dependent variable is the share of the total consumption aggregate that was taken from stocks. It is also expressed per adult equivalent. The fourth dependent variable is an indicator of nonfood spending per adult equivalent, which includes spending in terms of clothing, housing, leisure, transport and transfers during the last year. The fifth dependent variable is the tropical livestock units (TLU), which summarizes in one indicator the possession of a wide range of livestock, weighted according to their type and size ${ }^{15}$ In order to improve statistical power, the last variable is a summary index that aggregates information over the five main dependent variables (Kling et al, 2007). The summary index is defined to be the equally weighted average of z-scores of the five components. The z-scores are calculated by subtracting the mean for civilian households and dividing by the standard deviation for civilian households for each component. Descriptive statistics are presented in table 1 .

All the household welfare indicators have decreased on average between 2006 and 2010. This trend shows that living conditions have deteriorated in these three provinces of Burundi during that period. Meanwhile, household size increased during the same period. Table 1 suggests that attriting households purchased more, had fewer stocks, were smaller and were more affected by the conflict. Attrition is discussed in more detail at the end of this section.

The dummies $R_{i}^{F N L}$ and $R_{i}^{C N D D+}$ are equal to one for returnee households. This category includes all households that declared having one member with ties to the factions, whether or not they benefited from DDR allowances. ${ }^{16}$

The dummies $D_{i}^{F N L}$ and $D_{i}^{C N D D+}$ refer to demobilized households, that is, returnee households with a member who benefited from the reinsertion grants. We constructed these dummies according to three definitions, provided in table 2 along with the corresponding number of excombatants falling into that category. In the first definition, demobilized ex-combatants are those who declared ties to a faction and were registered in the official demobilization registers $\left(D_{i}^{F N L 1}\right.$ and $\left.D_{i}^{C N D D+1}\right)$. In order to minimize misreporting, the second definition adds house-

\footnotetext{
${ }^{15}$ Conversion factors used are the following: cattle (0.50), sheep and goats $(0.10)$, pigs $(0.20)$, poultry and rabbits (0.01) (Harvest Choice, 2011).

${ }^{16}$ Returnees include demobilized households, but also "gardien de la paix", "adultes associés", "militant combatant", and people without any status but that declared themselves as members of a rebel faction.
} 
Table 1: Descriptive statistics

\begin{tabular}{|c|c|c|c|c|c|}
\hline & \multicolumn{3}{|c|}{ Sample mean (sd) } & \multicolumn{2}{|c|}{ T-test $p$-value } \\
\hline & 2010 & 2006 & Attrition & $\begin{array}{l}2010 / \\
2006\end{array}$ & $\begin{array}{c}2006 / \\
\text { attrition }\end{array}$ \\
\hline \multicolumn{6}{|l|}{ Economic outcomes } \\
\hline Consumption per $\mathrm{AE}$ & $\begin{array}{r}14387 \\
(11349)\end{array}$ & $\begin{array}{c}16101 \\
(10996)\end{array}$ & $\begin{array}{c}17706 \\
(14716)\end{array}$ & 0.00 & 0.15 \\
\hline Cons. expenditure per $\mathrm{AE}$ & $\begin{array}{l}7971 \\
(7045)\end{array}$ & $\begin{array}{l}8828 \\
(7765)\end{array}$ & $\begin{array}{c}11314 \\
(11155)\end{array}$ & 0.01 & 0.00 \\
\hline Cons. from stock per $\mathrm{AE}$ & $\begin{array}{l}6566 \\
(9281)\end{array}$ & $\begin{array}{l}7246 \\
(8181)\end{array}$ & $\begin{array}{l}6114 \\
(8679)\end{array}$ & 0.08 & 0.09 \\
\hline Nonfood spending per $\mathrm{AE}$ & $\begin{array}{l}47191 \\
(148397)\end{array}$ & $\begin{array}{c}26478 \\
(78022)\end{array}$ & $\begin{array}{c}31776 \\
(70344)\end{array}$ & 0.00 & 0.32 \\
\hline Tropical livestock units & $\begin{array}{l}0.09 \\
(0.16)\end{array}$ & $\begin{array}{l}0.16 \\
(0.19)\end{array}$ & $\begin{array}{l}0.09 \\
(0.19)\end{array}$ & 0.00 & 0.03 \\
\hline \multicolumn{6}{|l|}{ Demographic characteristics } \\
\hline Adult equivalent (AE) & $\begin{array}{l}2.90 \\
(0.92)\end{array}$ & $\begin{array}{l}2.66 \\
(0.88)\end{array}$ & $\begin{array}{l}2.48 \\
(0.80)\end{array}$ & 0.00 & 0.00 \\
\hline HH size & $\begin{array}{l}5.89 \\
(2.34)\end{array}$ & $\begin{array}{l}5.37 \\
(2.34)\end{array}$ & $\begin{array}{l}4.91 \\
(2.21)\end{array}$ & 0.00 & 0.00 \\
\hline Sex Head & $\begin{array}{l}0.78 \\
(0.42)\end{array}$ & $\begin{array}{l}0.80 \\
(0.40)\end{array}$ & $\begin{array}{l}0.81 \\
(0.40)\end{array}$ & 0.13 & 0.94 \\
\hline Age Head & $\begin{array}{l}46 \\
(14)\end{array}$ & $\begin{array}{l}42 \\
\text { (14) }\end{array}$ & $\begin{array}{l}41 \\
(16)\end{array}$ & 0.00 & 0.37 \\
\hline \multicolumn{6}{|l|}{ Head education } \\
\hline No school & $\begin{array}{l}0.37 \\
(0.48)\end{array}$ & $\begin{array}{l}0.36 \\
(0.48)\end{array}$ & $\begin{array}{l}0.34 \\
(0.47)\end{array}$ & 0.78 & 0.49 \\
\hline Primary school & $\begin{array}{l}0.38 \\
(0.49)\end{array}$ & $\begin{array}{l}0.36 \\
(0.48)\end{array}$ & $\begin{array}{l}0.41 \\
(0.49)\end{array}$ & 0.47 & 0.22 \\
\hline Secondary school & $\begin{array}{l}0.04 \\
(0.20)\end{array}$ & $\begin{array}{l}0.03 \\
(0.18)\end{array}$ & $\begin{array}{l}0.04 \\
(0.20)\end{array}$ & 0.20 & 0.43 \\
\hline Coranic school & $\begin{array}{l}0.21 \\
(0.41)\end{array}$ & $\begin{array}{l}0.24 \\
(0.43)\end{array}$ & $\begin{array}{l}0.21 \\
(0.41)\end{array}$ & 0.08 & 0.29 \\
\hline \multicolumn{6}{|l|}{ Head marital status } \\
\hline Single & $\begin{array}{l}0.02 \\
(0.15)\end{array}$ & $\begin{array}{l}0.03 \\
(0.16)\end{array}$ & $\begin{array}{l}0.04 \\
(0.20)\end{array}$ & 0.70 & 0.20 \\
\hline Married & $\begin{array}{l}0.76 \\
(0.43)\end{array}$ & $\begin{array}{l}0.79 \\
(0.40)\end{array}$ & $\begin{array}{l}0.76 \\
(0.43)\end{array}$ & 0.07 & 0.28 \\
\hline Divorced & $\begin{array}{l}0.02 \\
(0.15)\end{array}$ & $\begin{array}{l}0.02 \\
(0.13)\end{array}$ & $\begin{array}{l}0.03 \\
(0.17)\end{array}$ & 0.25 & 0.25 \\
\hline Widow & $\begin{array}{l}0.19 \\
(0.39)\end{array}$ & $\begin{array}{l}0.16 \\
(0.37)\end{array}$ & $\begin{array}{l}0.16 \\
(0.37)\end{array}$ & 0.09 & 0.97 \\
\hline Occupation & & & & & \\
\hline Agriculture & $\begin{array}{l}0.79 \\
(0.41)\end{array}$ & $\begin{array}{l}0.79 \\
(0.41)\end{array}$ & $\begin{array}{l}0.78 \\
(0.42)\end{array}$ & 0.97 & 0.68 \\
\hline Small business & $\begin{array}{l}0.12 \\
(0.32)\end{array}$ & $\begin{array}{l}0.08 \\
(0.27)\end{array}$ & $\begin{array}{l}0.07 \\
(0.25)\end{array}$ & 0.00 & 0.51 \\
\hline Construction & $\begin{array}{l}0.04 \\
(0.20)\end{array}$ & $\begin{array}{l}0.06 \\
(0.23)\end{array}$ & $\begin{array}{l}0.09 \\
(0.29)\end{array}$ & 0.09 & 0.09 \\
\hline Public sector & $\begin{array}{l}0.02 \\
(0.16)\end{array}$ & $\begin{array}{l}0.04 \\
(0.19)\end{array}$ & $\begin{array}{l}0.02 \\
(0.13)\end{array}$ & 0.09 & 0.05 \\
\hline Extractive activities & $\begin{array}{l}0.03 \\
(0.16)\end{array}$ & $\begin{array}{l}0.01 \\
(0.09)\end{array}$ & $\begin{array}{l}0.00 \\
(0.07)\end{array}$ & 0.00 & 0.41 \\
\hline Colline characteristics (village level & & & & & \\
\hline Violent events (last 4 years) & $\begin{array}{l}0.44 \\
(0.86)\end{array}$ & $\begin{array}{l}1.14 \\
(1.63)\end{array}$ & $\begin{array}{c}1.39^{a} \\
(1.71)\end{array}$ & 0.00 & $0.00^{b}$ \\
\hline Ex-combatant Return, per 1000 & $\begin{array}{l}3.76 \\
(5.43) \\
\end{array}$ & $\begin{array}{l}2.99 \\
(4.48) \\
\end{array}$ & $\begin{array}{c}3.00^{a} \\
(5.15) \\
\end{array}$ & 0.31 & $0.00^{b}$ \\
\hline
\end{tabular}


holds from which individuals were matched ${ }^{17}$ with the official demobilization registers $\left(D_{i}^{F N L 2}\right.$ and $D_{i}^{C N D D+2}$ ). The third definition is based on self-reported data, and includes anyone who declared to be demobilized, that is, to have received the cash $\left(D_{i}^{F N L 3}\right.$ and $\left.D_{i}^{C N D D+3}\right)$. The last definition is more likely to contain measurement errors as it is based on self-reports; its associated coefficients will presumably be biased towards zero (Hausman, 2001). The three different indicators will be compared in the empirical analysis. 18

Table 2: Construction of ex-rebel household variables

\begin{tabular}{|c|c|c|c|c|c|}
\hline & \multirow[t]{2}{*}{ CNDD+ } & \multirow[t]{2}{*}{$\overline{\mathrm{FNL}}$} & \multirow[t]{2}{*}{ Total } & \multicolumn{2}{|c|}{ Variable of interest } \\
\hline & & & & CNDD+ & FNL \\
\hline \multicolumn{6}{|l|}{ Member declared having ties with the factions } \\
\hline but did not receive anything & 8 & 10 & 18 & & \\
\hline and to be $\mathrm{GdP} / \mathrm{MC} / \mathrm{AA}$ & 6 & 4 & 10 & & \\
\hline \multicolumn{6}{|l|}{ Demobilized ex-combatant member } \\
\hline Member declared to be demobilized & 14 & 9 & 23 & $D_{i}^{C N D D+3}$ & $D_{i}^{F N L 3}$ \\
\hline And not recorded in official registers & 8 & 5 & 13 & & \\
\hline And recorded in official registers & 6 & 4 & 10 & $D_{i}^{C N D D+1}$ & $D_{i}^{F N L 1}$ \\
\hline Not declared but matched with registers & 1 & 7 & 8 & & \\
\hline Total matched with registers (declared or not) & 7 & 11 & 18 & $D_{i}^{C N D D+2}$ & $D_{i}^{F N L 2}$ \\
\hline \multicolumn{6}{|l|}{ Totals } \\
\hline Households belonging to a faction (without matches) & 28 & $21^{*}$ & 49 & $R_{i}^{C N D D+1}$ & $R_{i}^{F N L 1}$ \\
\hline Households belonging to a faction (with matches) & 29 & 28 & 57 & $R_{i}^{C N D D+2}$ & $R_{i}^{F N L 2}$ \\
\hline
\end{tabular}

We argue that the second definition is the most appropriate for two reasons. First, the matching exercise with official demobilization registers should capture respondents who feared reporting that there is an ex-combatant in their family. Second, cross-checking self-reported demobilization status with official demobilization registers should exclude households who wrongly

\footnotetext{
${ }^{17}$ We undertook this matching exercise using generalized Levenshtein edit distance, which is the total number of insertions, deletions and substitutions required to transform one string into another. We matched the names, age, sex and the code of the colline of return of the ex-combatants listed in the official demobilization registers with the household information available in our panel dataset. We use a maximum number of transformation of 2 for string variables (first name, last name, both), a range of $[-10,+10]$ from the age reported, and the match had to be perfect for the colline's code and gender. We did this exercise twice, once matching each entry in the registers to the panel data; and once the other way around. As names are very similar in Burundi, and many people can have the same last name (all twins have the same last names; siblings' last names are different and are chosen according to various contextual factors), we made sure to only consider as matches cases where names contain typos. We found eight matches, which supports the fact that we were very restrictive.

${ }^{18}$ One should note that the number of registered ex-combatants in our sample is representative of the true excombatants' density and that an over-sampling of ex-combatants was not compatible with having a panel.
} 
categorized themselves as having benefited from demobilization allowances. Indeed, many people helped the rebels during the war and they may have wrongly categorized themselves as demobilized ex-combatants. Similarly, some respondents may have claimed to be demobilized in expectation of rewards in exchange for their participation to the survey.

The short-run direct impact of the DDR program is measured by the dummies $R_{i}^{F N L}$ and $D_{i}^{F N L}$. In particular, the coefficient $\beta_{1}$ measures the impact of having a FNL returnee in the household who did not benefit from reinsertion allowances. The coefficient $\beta_{2}$ measures the marginal impact of having benefited from the FNL reinsertion allowance ${ }^{19}$ We therefore compare the returnee households that have received the grant (demobilized) to the returnee households that reported having a member who was part of the FNL but did not receive reinsertion grants (hypothesis 1).

The variables $R_{i}^{C N D D+}$ and $D_{i}^{C N D D+}$ capture the long-run evolution of outcomes for CNDD+ households (hypothesis 2). To interpret the coefficients associated with these variables, we need to carefully consider the timing of the demobilization of CNDD+ combatants, which started before the first survey at the end of 2004. Thus, by the time of the QUIBB survey, which is used as our baseline, these ex-combatants had already benefited from reinsertion allowances. Then, they benefited from the in-kind reintegration grants between both surveys. Hence, we are not able to measure the long-term impact of the program on their economic outcomes. What we can assess however, is the evolution of their economic outcomes between the two surveys.

We explain this argument formally. In an ideal scenario in which we would have had data before the peace agreement, let $\sigma$ denote the short-run impact of the demobilization program, that is, the one-year impact between the reception of the allowances and the QUIBB survey. Similarly, $\lambda$ denotes the measure of the long-run impact of the demobilization program, that is, the five-year impact between the reception of the allowances and the 2010 panel survey. Unfortunately, we are not able to measure $\sigma$ and $\lambda$ separately. However, we can capture the difference $\eta=\lambda-\sigma$, which can be thought of as the long-run evolution of the economic outcomes of CNDD+ ex-combatants. Therefore, in equation (1), the coefficient $\eta_{1}$ measures the evolution of outcomes for returnee CNDD+ households that did not benefit from the DDR, and the coefficient $\eta_{2}$ measures the differential evolution for CNDD+ demobilized households ${ }^{20} \mathrm{We}$ recommend caution when comparing the impacts of the DDR on FNL and CNDD+ demobilized

\footnotetext{
${ }^{19}$ Some of the returnees have benefited from the FBU 100,000 (US\$ 91) allocated to "Gardiens de la Paix", "Militants Combatants" and "Adultes Associés". We do not have access to registers to verify which households benefited from these reduced grants. Our empirical analysis will therefore slightly underestimate the effect of the demobilization program.

${ }^{20}$ In table $\mathrm{S} .5$ in appendix, we show descriptive statistics disaggregated by demobilization status and faction along with seven joint tests of equality of means between the nondemobilized households and the civilians, and the nondemobilized and demobilized within and between faction. The statistics related to the demobilized are computed considering the second definition in table 2 .
} 
combatants given the differences in the timing, the type, and the size of the benefits received by these two groups.

We measure the indirect impact of the demobilization program on civilians by looking at the proportion per 1,000 people of ex-combatants living in each colline ${ }^{21}$ (hypothesis 3 ). The variables of interest are denoted $S_{i}^{C N D D+}$ for the proportion of ex-combatants demobilized between 2004 and 2006 and $S_{i}^{F N L}$ for the proportion of ex-combatants demobilized after 2009. The coefficient $\beta_{3}$ gives "a community average effect" of having more or less demobilized FNL combatants when the direct effect on those who received the money is controlled for. In this sense, it captures the indirect effect of the FNL demobilization program on civilians. Similarly, the coefficient $\eta_{3}$ captures the long-run evolution of spillovers generated by the demobilization of CNDD+ combatants. On average, there were 3.8 ex-combatants per 1000 inhabitants that came back following the first wave of the program from 2004 onwards. The FNL demobilization process of 2009 led to an average of 3 ex-combatant returns per 1000 inhabitants. There are substantial differences between collines, which are highlighted in figure 3 for our provinces of interest. These maps present the distribution of ex-combatants in each colline, scaled by population.

Figure 3: Demobilized ex-combatants per 1000 inhabitants in Bujumbura Rural, Bubanza and Cibitoke provinces

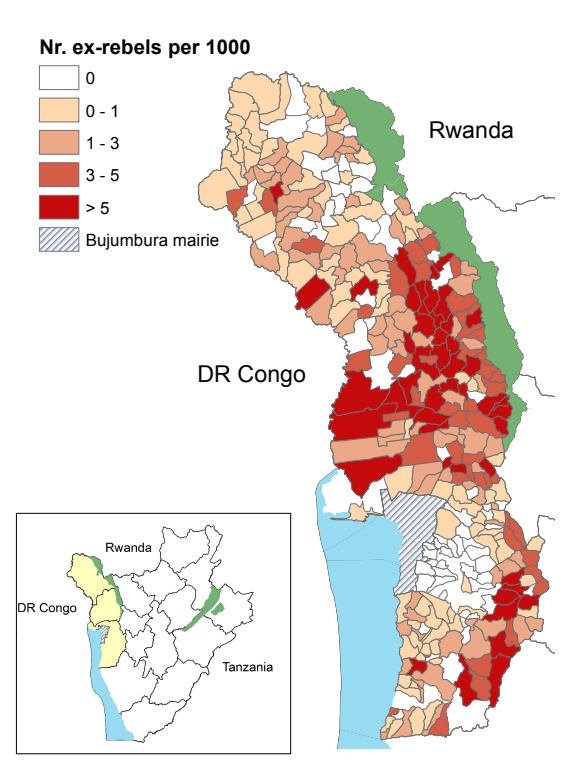

(a) CNDD+ per 1000

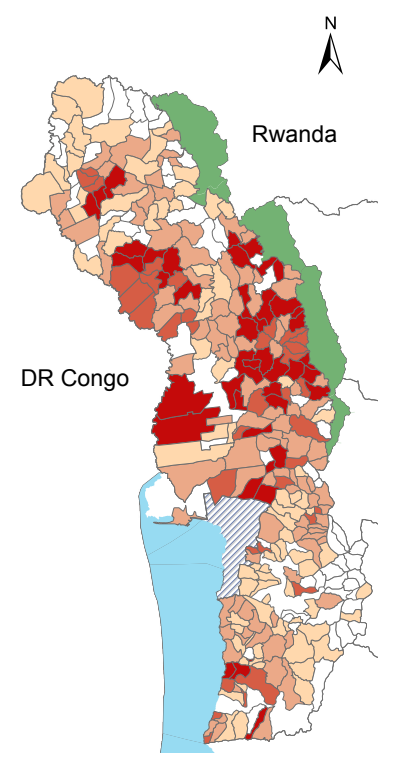

(b) FNL per 1000

Source: Authors' analysis based on data described in the text.

\footnotetext{
${ }^{21}$ Note that this indicator is computed at the colline level, which is one administrative level above the villages sampled ("sous-colline"). We therefore consider ex-combatant returns in the village of the household, as well as in neighboring villages. While the villages may be connected to each other, the collines are not. Given the size of collines and the difficulties to move in the country, it is very unlikely that the returns in one colline have affected neighboring collines.
} 
The vector $X_{i}$ regroups several control variables that may explain changes in economic outcomes between the two rounds of the panel. It includes the sex, age, education, and marital status of the household head, a dummy that accounts for a change of household head between 2006 and 2010, and the main occupation of households. These variables are not first-differenced to avoid the multicollinearity problem. We also control for past violence, using two variables measuring the number of violent events that occurred in the colline before and after the baseline survey. Summary statistics are presented in table 1 . Variables that we expect to have been affected by the demobilization program, such as production, land or other assets, are excluded from the regression (they can be considered as "bad controls" (Angrist and Pischke, 2008)). We include province fixed effects $Z_{k}$. Standard errors are clustered at the colline level to account for intra-cluster correlation. Sampling weights are accounted for. ${ }^{22}$ Outliers are excluded from the regressions (see appendix B.1 for more details).

Before presenting the results, we discuss the problem of attrition by following the methods proposed by Becketti et al (1988) and Fitzgerald et al (1998) and applied by Alderman et al (2001, 2006). The analysis of table 1 suggests that attriting households purchased more, have fewer stocks, are smaller and were more affected by the conflict. Attrition could bias the estimations if it is selective, that is, if the relationship of interest is different for households that were observed and for households that attrited. To test if selective attrition is likely to bias our results, we first estimated the determinants of our dependent variables in 2006 separately for traced and attriting households (Becketti et al, 1988). Fortunately, we do not reject the null hypothesis that the coefficients of these regressions are the same (table S.1 in appendix). Second, we estimated a Probit model to test whether attrition is correlated with dependent variables (Fitzgerald et al, 1998). As shown in appendix (table S.2), the dependent variables are not significantly correlated with the probability of being sampled both with and without controls. We conclude that differential attrition is unlikely to be a concern in our analysis.

\section{Results}

Table 3 presents the estimation of the lagged dependent variable model in which the dependent variable is the change in the log of the total consumption per adult equivalent. It shows that there is no significant difference between the consumption per adult equivalent of FNL returnee households that did not benefit from reinsertion allowances and the consumption per adult equivalent of civilian households. However, having benefited from the demobilization program had a large impact on the consumption of FNL demobilized households (hypothesis 1). The coefficient of the variable $D_{i}^{F N L}$, which measures the short-run direct effect of the cash

\footnotetext{
${ }^{22}$ The results are similar if we do not use the sampling weights.
} 
transfer, is positive, significant, and strikingly high when self-reported information about demobilization status is cross-checked against official demobilization registers (columns [1] to [4]). It suggests that the consumption of demobilized FNL households is between $77 \%$ and $144 \%$ higher ${ }^{23}$ than the consumption levels of FNL returnee households that did not benefit from reinsertion allowances but had the same consumption level in 2006 as the demobilized households. This effect is also positive when using the definition of demobilization status based on self-reported information (columns [5] and [6]), but it loses its significance. This reduced precision can be explained by the presence of noise due to misreporting (Hausman, 2001).

The long-run evolution of total consumption per adult equivalent does not seem to differ between civilian households and CNDD+ returnee households that did not benefit from the DDR. In contrast, the long-run evolution of total consumption turns out to be negative for households that benefited from the first wave of the DDR program from 2004 (hypothesis 2). The coefficient of the variable $D_{i}^{C N D D+}$ is significant and large but negative. These estimates suggest that the consumption of CNDD+ households that benefited from the first wave of the program is between $40 \%$ and $50 \%$ lower in 2010 than the total consumption of nonbeneficiary CNDD+ households that had the same consumption level in 2006 as beneficiary households. This observation holds for all three definitions. The coefficients associated with the variables $D_{i}^{F N L}$ and $D_{i}^{C N D D+}$ are of similar size, but of opposite sign (the F-test $p$-values reported at the bottom of table 3 are above 0.48 for all specifications).

Table 3 also highlights the presence of spillovers (hypothesis 3). The coefficient associated with the proportion of ex-FNLs in collines $S_{i}^{F N L}$ is positive and significant. This result suggests that households living in collines with a large number of demobilized ex-combatants benefited from positive spillovers. By contrast, the coefficient of the variable $S_{i}^{C N D D+}$ is negative and significant, showing that in the long run, households living in areas with numerous CNDD+ ex-combatants consumed on average less in 2010 than households who had a similar standard of living in 2006 and who lived in areas with fewer CNDD+ ex-combatants. The coefficients associated with the variables $S_{i}^{F N L}$ and $S_{i}^{C N D D+}$ are of similar size, but of opposite sign across definitions (F-test $p$-values are all above 0.78 ).

Finally, the coefficient associated with the lagged dependent variable is negative and significant. This further illustrates the importance of including the lagged dependent variables in the regressions to account for low auto-correlation, noise, or catch-up effects in the outcomes of interest.24

Table 4 displays the estimates of the lagged dependent variable model for the five other

\footnotetext{
${ }^{23}$ As the dependent variables of the regressions are expressed in $\log$, the interpretation of the coefficients in terms of percentage should be corrected according to the formula: $e^{\text {coef. }}-1$.

${ }^{24}$ As shown in table $\mathrm{S} .4$ in appendix, the coefficients associated with the long-run indirect effect lose significance when we do not control for the lagged dependent variables.
} 
Table 3: Lagged dependent variable model - Aggregate consumption

Dependent variable: $\Delta$ Log total consumption per AE in 2010

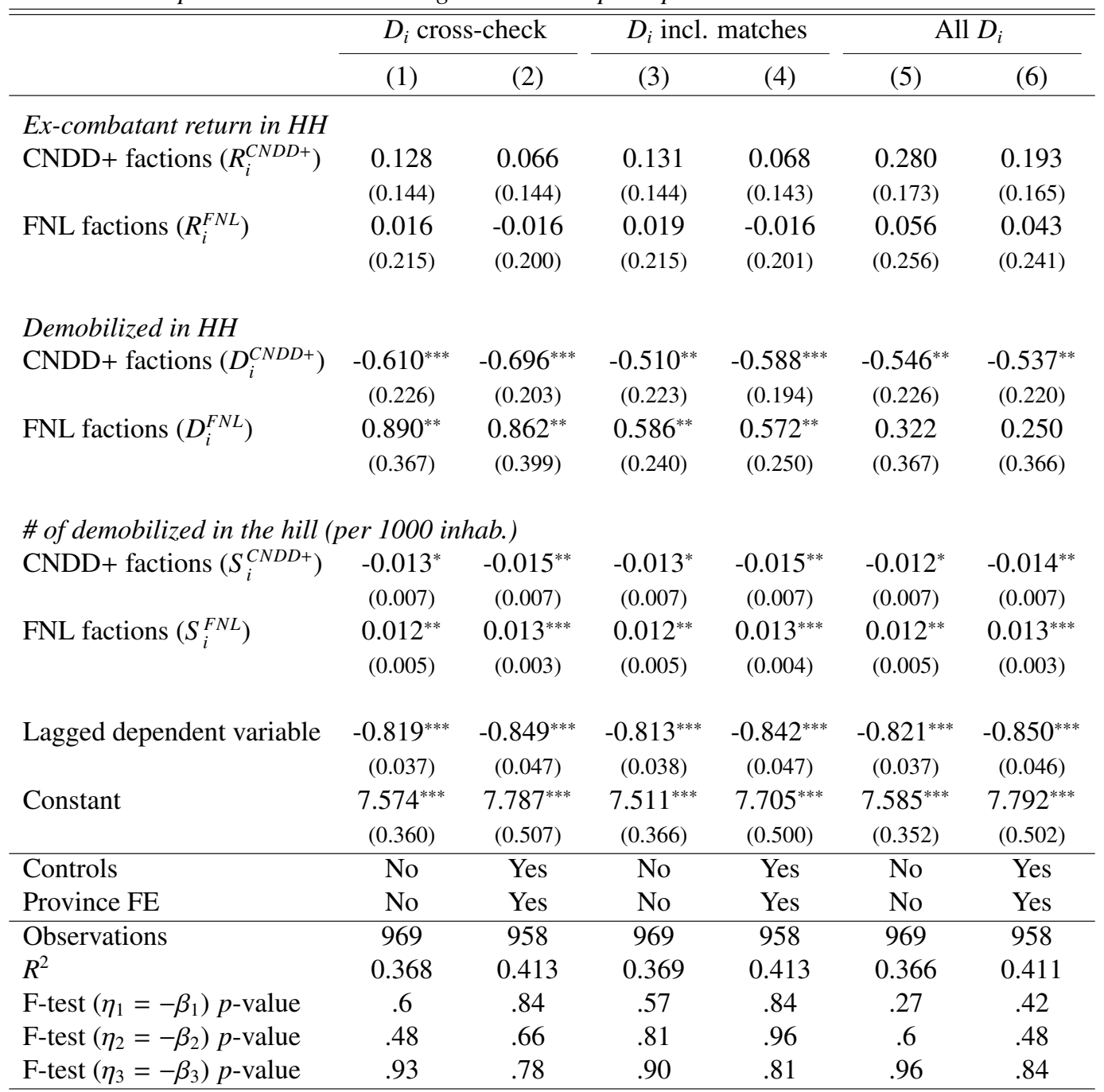

Notes: Authors' analysis based on data described in the text. In this table, we compare the three definitions of demobilization, with and without controls and province fixed effects. The table reports OLS estimates. The unit of observation is a household. Total consumption is the sum of consumption expenditures and consumption taken from households' stocks per adult equivalent. In column (1) and (2), $D_{i}$ only included ex-combatants cross-checked with official registers. In column (3) and (4), $D_{i}$ adds matches. In column (5) and (6), all self-reported ex-combatants are included. Odd-numbered columns do not include control variables or fixed effects; the remaining columns include both. We report the $p$-values of F-tests assessing whether the coefficients associated with CNDD+ and FNL variables are of similar size, but of opposite sign. Controls include past violence, whether the household head changed, his sex, age, matrimonial status, education, and occupation. Outliers are excluded (as explained in Appendix B.1. Sampling weights are accounted for. Clustered-robust standard errors are in parentheses. $* p<0.10, * * p<0.05, * * * p<0.01$

economic outcomes. This table relies on the second definition of demobilized ex-combatants, namely the one using self-reported information cross-checked with the official demobilization registers and supplemented with matches, ${ }^{25}$

\footnotetext{
${ }^{25} D_{i}^{C N D D+2}$ and $D_{i}^{F N L 2}$ in table 2 The use of other definitions leads to similar results. When self-reported information is used, the results are weakened by the presence of noise.
} 
Consumption expenditures, consumption from stocks, nonfood spending, livestock owning, and the summary index are significantly higher in households that benefited from the FNL demobilization program (hypothesis 1). Consumption expenditures of demobilized FNL households are on average $67 \%$ higher than consumption expenditures of FNL returnee households that did not benefit from reinsertion allowances (column [2]). Similarly, consumption from stocks is $144 \%$ higher (column [4]), nonfood purchases are $392 \%$ higher (column [6]), and the total livestock units are 10\% higher (column [8]).

The coefficient associated with the long-run evolution of demobilization variable for CNDD+ demobilized combatants exhibits interesting patterns (hypothesis 2). When the dependent variables involve spending money, as for consumption or nonfood purchases, the coefficients of the variable $D_{i}^{C N D D+2}$ are negative and significant (columns [2] and [6]). For these economic outcomes, the coefficient associated with the CNDD+ demobilization have the opposite signs of those associated with FNL demobilization but are of similar size (F-test $p$-values reported at the bottom of table 4 are not significant). In contrast, for variables associated with asset holdings such as consumption from stocks (which includes consumption from one's own agricultural production) and livestock, coefficients are close to zero and not significant. The coefficient associated with the variable $D_{i}^{C N D D+2}$ is negative but not significant at conventional thresholds when the dependent variable is the summary index ( $p$-values $=.13$ and .17 in columns [9] and [10] respectively).

The results we find for the spillovers of the DDR program are consistent with this picture (hypothesis 3). The effects of spillovers of the FNL demobilization on nonbeneficiaries are positive-around $2 \%$ - and significant for consumption expenditures, nonfood purchases, and the summary index. For these three dependent variables, the impact of spillovers from the CNDD+ demobilization are of similar size but of opposite sign. The spillovers to livestock follow a similar pattern, positive and significant for FNL demobilization, and negative and significant for CNDD+ demobilization. However, estimated coefficients are close to zero. There is no significant effect of spillovers on consumption from stocks.

\section{Discussion}

In this section, we discuss and interpret the empirical results in light of economic theory and we put them in perspective with regard to existing literature. We first focus on the direct impact on ex-combatants and then turn to the analysis of spillovers.

\subsection{Direct Effect of the DDR on Ex-combatants' Households}

Our first finding is the large positive impact of demobilization on the economic situation of households hosting a demobilized FNL (hypothesis 1). In the short run, the FNL demobilized households consumed more, spent more in nonfood items and had a larger stock of livestock. 
Table 4: Lagged dependent variable model - Disaggregated consumption, nonfood spending, Tropical livestock Units (TLU), and a summary index $Z$ that aggregates information over the five main dependent variables (Kling et al, 2007).

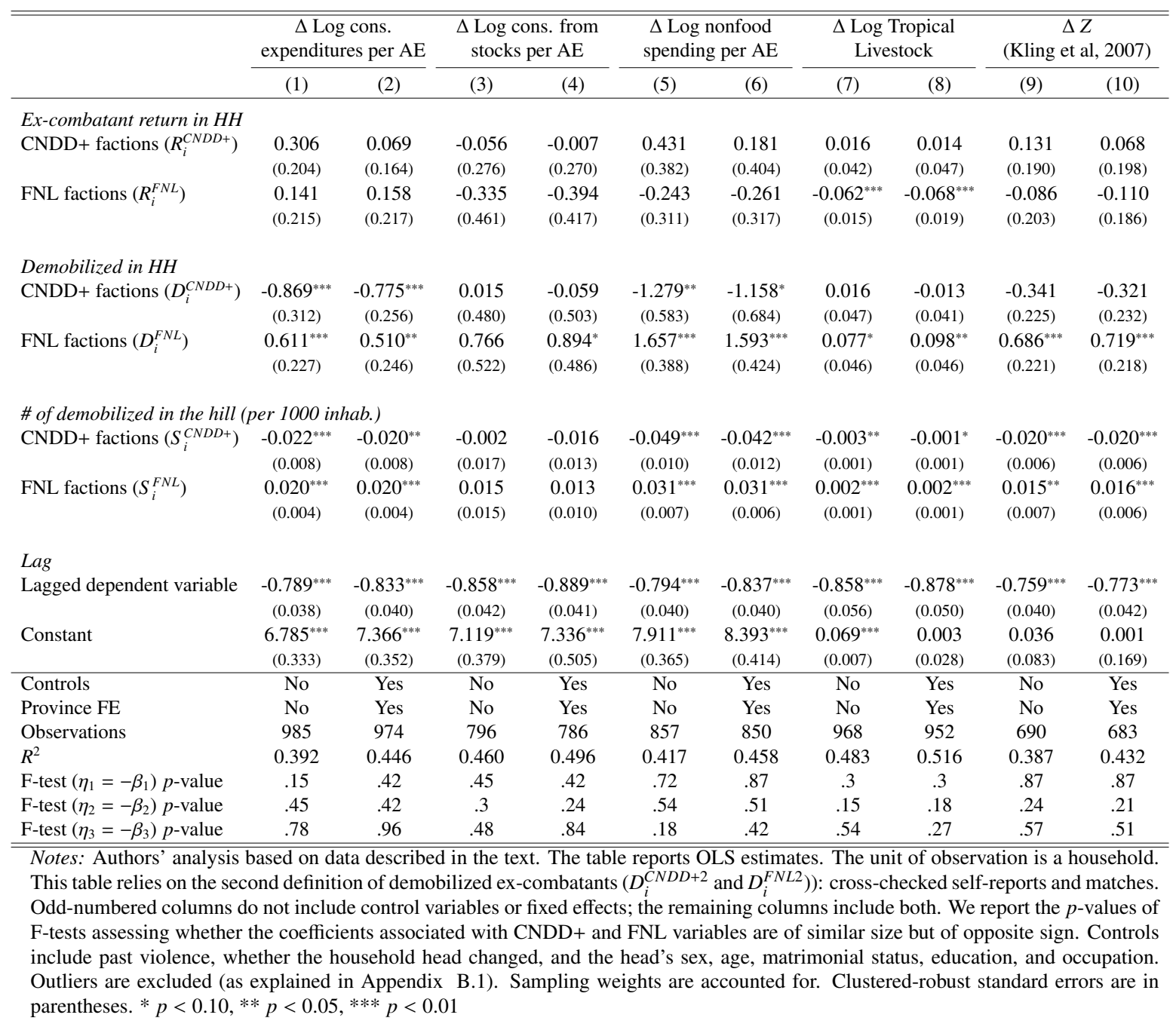

This finding is consistent with the theoretical framework, since at the time of the interviews, the demobilized FNLs were in the process of receiving the equivalent of 18-months' salary in four cash installments. In a context of poorly functioning financial savings institutions, ${ }^{26}$ none of the FNL households reported saving part of their allowance in financial assets. Instead, a large proportion of ex-FNLs reported buying consumption goods (46\%), buying clothes $(15 \%)$ and paying medical bills (8\%). This observation is consistent with previous qualitative evidence from Burundi as well. Uvin (2007) showed that some ex-combatants, depending on the region they returned to, faced immediate needs such as building houses, paying medical bills, and buy-

\footnotetext{
${ }^{26}$ Our community data reveals the absence of formal financial institutions in $84 \%$ of the collines surveyed. Informal financial institutions are also scarce, with $87.5 \%$ of the collines lacking such associations.
} 
ing food for their family. These arguments elucidate the substantial increase in consumption of ex-FNLs as they "fell into a lot of money" (Uvin, 2007). However, FNLs also used demobilization money to invest in land (69\%) and construction (8\%), to invest in an income generating activity (31\%), and to pay off debts (15\%). These investments can be regarded as rational forms of nonfinancial saving in the absence of financial savings institutions.

Our second finding is the negative evolution of spending indicators for demobilized CNDD+ between 2006 and 2010 (hypothesis 2). We have reason to believe that CNDD+ households also experienced a consumption boom after "falling into money" in 2004. For the same reasons than their FNL counterparts, they are likely to have spent most of their allowances in consumption goods or in investments that were not productive enough to sustain their consumption in the long run. This tendency would explain why we observe a decrease in their consumption between 2006 and 2010. An alternative explanation for our results is that we are actually measuring the continuation of a decreasing trend. In this scenario, this trend would not be due to the grants, but would rather be explained by unobservable characteristics correlated with having received the grants.

There is evidence supporting the first interpretation and discrediting the second. First, Verwimp and Bundervoet (2009) have shown that consumption by CNDD+ ex-combatants' households increased by 34\% between 1998 and 2007. Their second wave of data was collected after the start of the program and after ex-CNDD+ received their cash transfers. These data suggest that CNDD+ ex-rebels were not on a decreasing trend before 2007, which dismisses the second interpretation. Second, qualitative evidence suggests that ex-combatants spent a large share of their allowance in nonproductive ways: food, drinks or clothes. They are therefore likely to have experienced a consumption boom similar to ex-FNLs as of 2005. From our survey, we find that $50 \%$ of CNDD+ ex-combatants spent part of their allowance in consumption goods and 33.3\% in clothing; only 5.6\% reported having saved part of the allowances. Ndayiziga et al (2008) underlines the tendency of ex-combatants to "overspend the demobilization indemnities in an unorganized way, quickly putting them back into hardship", while Willems et al (2010) conclude that "although the total sum of the benefits given to ex-combatants was rather large, many of them found it difficult to effectively use it for their reintegration because they did not have the capacity to handle money." Third, our results are also consistent with the fact that the indicators related to the stocks of productive assets exhibit a constant trend, while consumption indicators exhibit a downward trend. According to our data, a substantial fraction of ex-combatants invested in a plot of land (39\%), in a small shop (28\%), in working material (22\%) or in livestock $(11 \%)$. These investments are more durable and hence still observable in 2010 (table 4 , columns [4] and [8]). On the contrary, the spike in food and nonfood spending was short-lived and vanished when ex-combatants ran out of demobilization money (table 4, columns (2) and (6)). Fourth, our interpretation is consistent with the evolution of total consumption percentile 
ranks of demobilized households. Between 2006 and 2010, the average consumption of FNL households increased from the $42^{\text {th }}$ percentile to the $76^{\text {th }}$ percentile. The evolution is almost the opposite for CNDD+ households: average consumption decreased from the $69^{\text {th }}$ to the $48^{\text {th }}$.

Finally, we relied on two more formal approaches. We applied the method proposed by Altonji et al (2005) and Bellows and Miguel (2009) to test whether our results are likely to be driven by unobservables. Results presented in appendix (table S.6) show that our findings cannot be plausibly explained entirely away by unobservables. To see whether the direct effect could be driven by factors or policies at the community level, we added colline fixed effects to our benchmark OLS regressions. Similar results are obtained, discrediting this explanation (table S.7).

These arguments support the interpretation that ex-combatants were not able to sustain the consumption levels reached during the boom. However, we cannot conclude whether the total effect of the program in the long run was positive or not. In particular, we are unable to test whether their consumption level before the onset of the DDR program in 2004 was higher or lower than their consumption level in 2010. In 2010, the average consumption of CNDD+ households was close to the median level in the population. The long-run effect of the reintegration phase of the program, that is, the in-kind transfers, seems to have been marginal for the CNDD+ ex-combatants, at least when compared to the large effect of reinsertion allowances on consumption. This small effect contrasts with Gilligan et al (2013), who find that reintegration grants have had a positive impact on self-reported income and decreased poverty incidence. However, they reckon that they are "evaluating program effects within a very short time frame" (Gilligan et al, 2013). The difference in indicators ${ }^{27}$ and in the time frame, as well as the lower statistical power associated with our demobilization variables, could explain why we reach different conclusions.

\subsection{Spillovers on Civilians}

In section 4 , we showed that one additional FNL demobilized combatant per 1000 inhabitants generated on average a $2 \%$ increase in consumption purchases and nonfood spending in 2010 (hypothesis 3). We also found that one additional CNDD+ ex-combatant per 1000 inhabitants generated a negative evolution of consumption indicators between 2006 and 2010 . Our preferred interpretation for these results is that the cash transfer distribution generated a local economic boom in villages hosting numerous ex-combatants, both for the CNDD+ and the FNL demobilization waves. However, the positive economic environment generated by the demobilization of CNDD+ combatants has become sluggish over time, as the surplus of money

\footnotetext{
${ }^{27}$ We only managed to collect precise income data for a minority of households, so we are not able to assess the impact of the program on income.
} 
brought by demobilized combatants gradually moved outside the local economy because households also purchased goods produced outside their villages.

Our interpretation is consistent with prices' variations in the collines (hypothesis 4). Economic theory predicts that a sudden increase in cash will push demand upwards, leading to a temporary increase in the prices of normal goods under general conditions. Table $S .8$ in appendix documents how median prices in the local markets have evolved given the intensity of returns in the villages ${ }^{28}$ In accordance with theory, we find that prices in 2010 were significantly higher in collines with a higher density of demobilized FNL ex-combatants. A one-standarddeviation increase in the density of demobilized FNL led to a $1.8 \%$ increase in median prices ( $p$-value $=.048)$. In contrast, the evolution of prices was negatively affected by the presence of CNDD+ ex-combatants. A one-standard-deviation increase in the density of CNDD+ demobilized combatants generated a $2.1 \%$ reduction in prices $(p$-value $=.021)$. While variations in prices are consistent with our story, we cannot formally test whether these variations are due to demand or supply changes since only final (equilibrium) prices are observed.

Our story is also consistent with the estimated differential impact according to professions (hypothesis 3). In order to study the differential impact of the DDR according to households' main occupation, table 5 adds interaction terms between the main occupation of households and the proportion of ex-combatants living in collines to equation (1). It is important to note that our data does not allow us to clearly distinguish supply-side from demand-side effects. In particular, it is difficult to measure how the supply of goods and services changed in communities with the return of ex-combatants, given the fact that we only have information about 15 households at most in each sous-colline.

Ex-combatants spent a large part of their money on food and traditional drinks, which are produced by farmers. Given the increase in demand and prices, farmers selling part of their production in the local market should have benefited from increased revenue ${ }^{29}$ In line with theoretical predictions, we find that farmers consumed on average more in villages where FNL returns were higher and less in collines where more CNDD+ returned. We find that construction workers also indirectly benefited from the program. The construction sector indeed gained from ex-combatants' investments in rebuilding houses. When returning home, around 10\% of ex-rebels invested part of their allowance in the construction of a dwelling. Some civilian households probably also invested in their housing following the end of the conflict. Again, construction workers living in collines with numerous CNDD+ demobilized ex-combatants seemed to experience a slight slowdown comparing 2010 to 2006 (although this effect is not significant

\footnotetext{
${ }^{28}$ We estimated a lagged dependent variable model with median prices at the colline level with product fixed effects.

${ }^{29}$ For the farming sector, the effect of the return of ex-combatants on the supply of goods is expected to be marginal, as a majority of households were already involved in farming before demobilization.
} 
in some specifications). Despite the consumption boom induced by demobilization cash transfers, we find that the DDR program had no significant indirect effect on shopkeepers. This surprising result may be due to an increasingly competitive environment following the return of demobilized combatants. Table S.9 in the appendix indeed shows that shop ownership increased for FNL households between 2006 and 2010, from 12\% to 45\% ( $p$-value = .12). In contrast, we find that shop ownership of CNDD+ households declined between 2006 and 2010, from 56\% to $30 \%$ ( $p$-value $=.29)$. These changes go in the direction consistent with our interpretation but are not significant at conventional levels. Increased competition could also explain why we observe a reduction in the price of bottled beers in collines characterized by a high density of demobilized FNL returns and a positive evolution in the price of bottled beers in collines with a high density of CNDD+ returns (table $\mathrm{S} .8$ in the appendix). Finally, the impact on public sector employees is striking and should be emphasized. The relative situation of public employees has sharply improved in collines with a high proportion of CNDD+ returns. On the contrary, public employees living in collines with numerous FNL ex-combatants are relatively worse off. This is not surprising if we remember that the actual president of Burundi, Pierre Nkurunziza, is the former leader of the CNDD-FDD rebel group; public employees working in collines with numerous CNDD+ ex-combatants may have been favored following his election in 2005.

An alternative explanation for our findings could be that collines hosting FNLs and CNDD+ ex-combatants were following different trends: a positive trend for FNL collines and a negative trend for CNDD+ collines. This explanation is unlikely for a few reasons. First, there is no evidence of strategic relocation of ex-combatants. The registers include data on village of origin and return. Comparing these for each of the ex-combatants, we find that around $88 \%$ have come back to their colline of origin, and $92 \%$ to their home municipality. Formally, our analysis of the relative influence of unobservables compared to observables suggests that our results are not driven by unobservable characteristics, such as the drivers of relocation (table S.6 in the appendix).

Second, when the proportion of CNDD+ demobilized soldiers is included in the analysis of Verwimp and Bundervoet (2009), the coefficient associated with these spillovers is positive and equal to $0.01(p$-value $=.04)$ without province fixed effects and $0.006(p$-value $=.13)$ with fixed effects (available upon request). Its size is hard to compare with that of our estimates as their sample is different. In 2007, they did not go to two of our three provinces (Bubanza and Bujumbura Mairie) because the situation was deemed too volatile. Moreover, we do not use the exact same specification and indicators. Nevertheless, this suggests that collines hosting numerous CNDD+ ex-combatants were following a positive trend between 1998 and 2007. 
Table 5: Channels - Spillovers and sector of activity

Dependent variable: $\triangle$ Log total consumption per AE in 2010

\begin{tabular}{|c|c|c|c|c|c|c|}
\hline & (1) & $(2)$ & (3) & (4) & $(5)$ & (6) \\
\hline \multicolumn{7}{|l|}{ Ex-combatant return in $\mathrm{HH}$} \\
\hline \multirow[t]{2}{*}{ CNDD+ factions $\left(R_{i}^{C N D D+}\right)$} & 0.233 & 0.137 & 0.213 & 0.114 & 0.143 & 0.047 \\
\hline & $(0.160)$ & $(0.161)$ & $(0.157)$ & $(0.158)$ & $(0.149)$ & $(0.146)$ \\
\hline FNL factions $\left(R_{i}^{F N L}\right)$ & -0.045 & -0.075 & -0.032 & -0.072 & -0.001 & -0.040 \\
\hline Demobilized in $\mathrm{HH}$ & $(0.257)$ & $(0.237)$ & $(0.251)$ & $(0.234)$ & $(0.219)$ & $(0.204)$ \\
\hline \multirow{2}{*}{ CNDD+ factions $\left(D_{i}^{C N D D+}\right)$} & $-0.611^{*}$ & -0.569 & $-0.524^{*}$ & $-0.512^{*}$ & $-0.687^{* * *}$ & $-0.678^{* * *}$ \\
\hline & $(0.349)$ & $(0.345)$ & $(0.304)$ & $(0.295)$ & $(0.238)$ & $(0.230)$ \\
\hline \multirow[t]{2}{*}{ FNL factions $\left(D_{i}^{F N L}\right)$} & $0.488^{*}$ & $0.494^{* *}$ & $0.496^{* *}$ & $0.511^{* *}$ & $0.587^{* *}$ & $0.597^{* *}$ \\
\hline & $(0.252)$ & $(0.243)$ & $(0.245)$ & $(0.242)$ & $(0.243)$ & $(0.242)$ \\
\hline \multicolumn{7}{|c|}{ \# of demobilized in the hill (per 1000 inhab.) } \\
\hline \multirow[t]{2}{*}{$\mathrm{CNDD}+$ factions $\left(S_{i}^{C N D D+}\right)$} & $-0.020^{* * *}$ & $-0.023^{* * *}$ & $-0.017^{* *}$ & $-0.019^{* * *}$ & $-0.017^{* *}$ & $-0.020^{* * *}$ \\
\hline & $(0.006)$ & $(0.006)$ & $(0.007)$ & $(0.007)$ & $(0.006)$ & $(0.006)$ \\
\hline \multirow[t]{2}{*}{ FNL factions $\left(S_{i}^{F N L}\right)$} & $0.018^{* * *}$ & $0.015^{* * *}$ & $0.018^{* * *}$ & $0.016^{* * *}$ & $0.018^{* * *}$ & $0.016^{* * *}$ \\
\hline & $(0.004)$ & $(0.004)$ & $(0.004)$ & $(0.004)$ & $(0.004)$ & $(0.004)$ \\
\hline \multicolumn{7}{|l|}{ Channel } \\
\hline \multirow{2}{*}{$S_{i}^{C N D D+} \times$ Small business } & $0.066^{* *}$ & $0.064^{* *}$ & $0.048^{*}$ & $0.051^{* *}$ & 0.014 & 0.016 \\
\hline & $(0.029)$ & $(0.028)$ & $(0.025)$ & $(0.023)$ & $(0.026)$ & $(0.025)$ \\
\hline \multirow{2}{*}{$S_{i}^{C N D D+} \times$ Construction } & -0.104 & $-0.096^{*}$ & -0.108 & -0.094 & -0.092 & -0.083 \\
\hline & $(0.068)$ & $(0.058)$ & $(0.067)$ & $(0.058)$ & $(0.083)$ & $(0.080)$ \\
\hline \multirow{2}{*}{$S_{i}^{C N D D+} \times$ Public sector } & $0.066^{* * *}$ & $0.061^{* * *}$ & $0.078^{* * *}$ & $0.069^{* * *}$ & $0.071^{* * *}$ & $0.060^{* * *}$ \\
\hline & $(0.016)$ & $(0.014)$ & $(0.016)$ & $(0.016)$ & $(0.015)$ & $(0.016)$ \\
\hline \multirow{2}{*}{$S_{i}^{C N D D+} \times$ Extractive activities } & 0.046 & 0.047 & 0.042 & 0.042 & 0.014 & 0.016 \\
\hline & $(0.042)$ & $(0.041)$ & $(0.042)$ & $(0.041)$ & $(0.026)$ & $(0.025)$ \\
\hline \multirow[t]{2}{*}{$S_{i}^{F N L} \times$ Small business } & $-0.022^{* *}$ & -0.015 & $-0.018^{* *}$ & -0.013 & -0.009 & -0.004 \\
\hline & $(0.011)$ & $(0.011)$ & $(0.008)$ & $(0.009)$ & $(0.008)$ & $(0.008)$ \\
\hline \multirow{2}{*}{$S_{i}^{F N L} \times$ Construction } & $0.283^{* * *}$ & $0.281^{* * *}$ & $0.292^{* * *}$ & $0.281^{* * *}$ & 0.134 & 0.125 \\
\hline & $(0.079)$ & $(0.073)$ & $(0.082)$ & $(0.078)$ & $(0.110)$ & (0.109) \\
\hline \multirow[t]{2}{*}{$S_{i}^{F N L} \times$ Public sector } & $-0.041^{* * * *}$ & $-0.032^{* * * *}$ & $-0.042^{* * *}$ & $-0.034^{* * *}$ & $-0.026^{* * *}$ & $-0.015^{* * * *}$ \\
\hline & $(0.004)$ & $(0.005)$ & $(0.005)$ & $(0.005)$ & $(0.004)$ & $(0.005)$ \\
\hline \multirow{2}{*}{$S_{i}^{F N L} \times$ Extractive activities } & $-0.021^{*}$ & -0.008 & $-0.021^{*}$ & -0.009 & $-0.021^{* * * *}$ & $-0.013^{*}$ \\
\hline & $(0.011)$ & $(0.011)$ & $(0.011)$ & $(0.011)$ & $(0.008)$ & $(0.008)$ \\
\hline \multicolumn{7}{|l|}{ Lag } \\
\hline \multirow[t]{2}{*}{ Log consumption per AE in 2006} & $-0.796^{* * * *}$ & $-0.822^{* * *}$ & $-0.816^{* * *}$ & $-0.840^{* * *}$ & $-0.821^{* * * *}$ & $-0.847^{* * * *}$ \\
\hline & $(0.054)$ & $(0.055)$ & $(0.052)$ & $(0.053)$ & $(0.044)$ & $(0.045)$ \\
\hline \multirow[t]{2}{*}{ Constant } & $7.339^{* * *}$ & $7.963^{* * *}$ & $7.506^{* * *}$ & $8.034^{* * * *}$ & $7.552^{* * * *}$ & $8.119^{* * *}$ \\
\hline & $(0.519)$ & $(0.578)$ & $(0.504)$ & $(0.566)$ & $(0.430)$ & $(0.516)$ \\
\hline Controls & No & Yes & No & Yes & No & Yes \\
\hline Province FE & No & Yes & No & Yes & No & Yes \\
\hline Observations & 858 & 853 & 909 & 904 & 963 & 958 \\
\hline$R^{2}$ & 0.097 & 0.133 & 0.088 & 0.121 & 0.070 & 0.102 \\
\hline
\end{tabular}

Notes: Authors' analysis based on data described in the text. This table reports OLS estimates for the secon definition of demobilization $\left(D_{i}^{C N D D+2}\right.$ and $\left.D_{i}^{F N L 2}\right)$. We grouped households into five employment categories: farming, small business, construction, public sector, and extractive activity. We define as the main occupation the one which generated the highest income the year before the survey. Constructing this variable was problematic for households that did not report the revenue associated with their activities. These households are therefore excluded in columns (1) and (2). In columns (3) and (4), households that did not report their revenue but only engaged in one type of activity are included. In columns (5) and (6), we also add the households that did not report their revenue and engaged in multiple activities by assuming that their main income generating activity was the nonagricultural one. In all columns, the dummy for farming activity - the main activity for $79 \%$ of households - is omitted. There are no controls in columns (1), (3), and (5). In the remaining columns, controls include whether the household head has changed, as well as the head's sex, age, matrimonial status, and education. Outliers are excluded (as explained in Appendix). Sampling weights are accounted for. Clustered-robust standard errors are in parentheses. $* p<0.10, * * p<0.05, * * * p<0.01$ 


\section{Concluding Remarks}

Following the end of the Cold War, multidimensional peacekeeping operations have been implemented to facilitate the transition from war to peace in Africa. Disarmament, demobilization, and reintegration programs have been an essential component of this process. These programs aim at "disarming combatants, removing them from military structures, and socially and economically integrating them into society" (World Bank 2009).

Burundi is recovering from a civil war that lasted more than a decade. The armed conflict ended in 2009 with the voluntary demobilization of the last Hutu rebel group, the PalipehutuFNL. In exchange for laying down their arms, ex-combatants received reinsertion allowances equivalent to an 18-month salary in the army. Four years before, another Hutu rebel group, the CNDD-FDD, benefited from the same allocations, and additionally received in-kind payments.

In this paper, we assessed the impact of this disarmament, demobilization, and reintegration program by analyzing a panel dataset collected in 2006 and 2010 in three rural provinces heavily affected by the conflict. Our objectives were to assess the short- and long-run impacts of the demobilization program on ex-combatants economic outcomes but also to capture the spillovers to civilian households.

Our empirical analysis highlighted the positive and significant impact of the demobilization program on ex-combatant households in the short run. The large amounts of money that were introduced in the local economy through the demobilization program generated an economic boom in the short run. As a result, households that did not participate actively in the conflict also indirectly gained from the demobilization program. In the long run, however, the positive impact of the DDR on beneficiaries and the positive externalities on nonbeneficiaries seem to have vanished as the money received by demobilized ex-combatants ran low.

The conclusions of our empirical analysis should be considered by policymakers while implementing DDR processes in other regions. In the short run, the positive direct effect of the DDR program shows that the program indeed provides a safety net to ex-combatants. The positive spillovers further show that the program does not only benefit beneficiaries but also communities where ex-combatants returned, increasing the range of impact. This second effect is likely to ease the return of ex-combatants to their villages. Our study therefore supports the reinsertion program implemented in postconflict countries as a short-run strategy to reduce the risk of relapse into conflict by alleviating poverty of both recipient and nonrecipient households. However, our results suggest that the reinsertion phase is not sufficient for creating a virtuous circle towards economic development, as the positive impact of cash transfers is short-lived. The return to a precarious economic situation may encourage ex-rebels to take up arms again and re-engage in violence (Colombo et al, 2014).

We emphasize three limitations of our study, which imply the need for further research. 
First, the absence of long-run positive effects associated with the subtler reintegration benefits could be due to the low predictive power given the small number of officially demobilized soldiers. Our analysis of spillover effects does not suffer from this caveat, as the combination of household panel data and the variation in the number of demobilized combatants across collines allowed us to quantify these effects both in the short and the longer run. Second, our analysis focused on an area in north-western Burundi in which ex-combatant density was above the country average, and it should not be seen as representative of the country. The theoretical framework highlighted that the impact of cash and in-kind transfers may vary according to the context and the way the program is implemented. More research is needed to assess the external validity of our findings. Finally, our interpretation of the evolution of the impact of the DDR program on CNDD+ demobilized combatants relies on the indirect observations of a short-run positive impact identified in the literature (Ndayiziga et al, 2008; Verwimp and Bundervoet, 2009; Willems et al, 2010). More research is needed to test the relevance of our interpretation and, more generally, to assess how impacts of demobilization programs evolve over time.

In spite of its limitations, we believe that our study sheds light on some important effects of the DDR program on both ex-combatants and civilians. We hope that our study, together with other analyses of the effects of the DDR program, can pave the way towards innovative designs for evaluating the impact of such important programs.

\section{References}

Ajayi, O. (2006) Experiences in the application of the core welfare indicator questionnaire (cwiq) survey technology in africa: the journey so far. The African Statistical Journal 3, 189-210.

Alderman, H., Behrman, J., Kohler, H.-P., Maluccio, J., Watkins, S. (2001) Attrition in Longitudinal Household Survey Data. Demographic Research 5(4), 79-124.

Alderman, H., Hoddinott, J., Kinsey, B. (2006) Long term Consequences of Early Childhood Malnutrition. Oxford Economic Papers 58(3), 450-474.

Altonji, J., Elder, T., Taber, C. (2005) Selection on Observed and Unobserved Variables : Assessing the Effectiveness of Catholic Schools. Journal of Political Economy 113(1), 151-184.

Angelucci, M., De Giorgi, G. (2009) Indirect Effects of an Aid Program: How Do Cash Transfers Affect Ineligibles' Consumption? The American Economic Review 99(1), 486-508.

Angrist, J., Pischke, J.-S. (2008) Mostly Harmless Econometrics: An Empiricist's Companion. Princeton University Press, Princeton, USA. 
Attanasio, O., Meghir, C., Santiago, A. (2012) Education choices in mexico: using a structural model and a randomized experiment to evaluate progresa. The Review of Economic Studies 79(1), 37-66.

Baird, S., McIntosh, C., Özler, B. (2011) Cash or Condition? Evidence from a Cash Transfer Experiment. The Quarterly journal of economics 126(4), 1709-1753.

Banerjee, A., Mullainathan, S. (2010) The shape of temptation: Implications for the economic lives of the poor. National Bureau of Economic Research, no. 15973.

Barrientos, A., Sabatés-wheeler, R. (2009) Do transfers generate local economy effects? BWPI Working Paper, no. 106.

Becketti, S., Gould, W., Lillard, L., Welch, F. (1988) The Panel Study of Income Dynamics after Fourteen Years : An Evaluation. Journal of Labor Economics 6(4), 472-492.

Bellows, J., Miguel, E. (2009) War and Local Collective Action in Sierra Leone. Journal of Public Economics 93(11), 1144-1157.

Besley, T. (1995) Savings, Credit and Insurance. In: Chenery, H., Srinivasan, T. (eds) Handbook of development economics, vol 3, Elsevier, Amsterdam, The Netherlands.

Blattman, C., Fiala, N., Martinez, S. (2014) Generating Skilled Self-Employment in Developing countries: Experimental Evidence from Uganda. Quarterly Journal of Economics 129(2), $697-752$.

Block, S. A. (1999) Agriculture and Economic growth in Ethiopia: Growth Multipliers from a Four-sector Simulation Model. Agricultural Economics 20(3), 241-252.

Bobonis, G. J., Finan, F. (2009) Neighborhood Peer Effects in Secondary School Enrollment Decisions. The Review of Economics and Statistics 91(4), 695-716.

Colombo, A., D’Aoust, O., Sterck, O. (2014) From Rebellion to Electoral Violence Evidence from Burundi. ECARES Working Papers, no. 33.

Cunha, J. (2014) Testing Paternalism: Cash versus In-Kind Transfers. American Economic Journal: Applied Economics 6(2), 195-230.

Cunha, J. M., De Giorgi, G., Jayachandran, S. (2011) The Price Effects of Cash versus In-kind Transfers. National Bureau of Economic Research, no. 17456.

D’Aoust, O., Sterck, O., Verwimp, P. (2013) Buying peace: The mirage of demobilizing rebels. HiCN Working Paper, no. 145. 
Deaton, A., Zaidi, S. (2002) Guidelines for Constructing Consumption Aggregates for Welfare Analysis. World Bank, Washington, USA.

Duflo, E. (2003) Grandmothers and Granddaughters: Old-Age Pensions and Intrahousehold Allocation in South Africa. The World Bank Economic Review 17(1), 1-25.

Evans, D., Popova, A. (2014) Cash Transfers and Temptation Goods: a Review of Global Evidence. World Bank Policy Research Working Paper, no. 6886.

Fafchamps, M., McKenzie, D., Quinn, S., Woodruff, C. (2011) When is Capital Enough to Get Female Microenterprises Growing? Evidence from a Randomized Experiment in Ghana. National Bureau of Economic Research, no. 17207.

Filipski, M., Taylor, J., Thome, K., Davis, B. (2015) Effects of treatment beyond the treated: a general equilibrium impact evaluation of lesotho's cash grants program. Agricultural Economics 46(2), 227-243.

Fitzgerald, J., Gottschalk, P., Moffitt, R., Gottschalk, P., Moffitt, R. (1998) An Analysis of Sample Attrition in Panel Data The Michigan Panel Study of Income Dynamics. The Journal of Human Resources 33(2), 251-299.

Gertler, P., Martinez, S., Rubio-Codina, M. (2012) Investing Cash Transfers to Taise Long-Term Living Standards. American Economic Journal: Applied Economics 4(1), 164-192.

Gilligan, M., Mvukiyehe, E., Samii, C. (2013) Reintegrating Rebels into Civilian Life: QuasiExperimental Evidence from Burundi. Journal of Conflict Resolution 57(4), 598-626.

Glennerster, R., Takavarasha, K. (2013) Running Randomized Evaluations: A Practical Guide. Princeton University Press, Princeton, USA.

Haggblade, S., Hammer, J., Hazell, P. (1991) Modeling agricultural growth multipliers. American Journal of Agricultural Economics 73(2), 361-374.

Harvest Choice (2011) Total livestock population (TLU) (2005). HarvestChoice, International Food Policy Research Institute, Washington, USA.

Haushofer, J., Shapiro, J. (2014) Household Response to Income Changes: Evidence from an Unconditional Cash Transfer Program in Kenya. Mimeo.

Hausman, J. (2001) Mismeasured Variables in Econometric Analysis : Problems from the Right and Problems from the Left. Journal of Economic Perspectives 15(4), 57-67. 
Hidrobo, M., Hoddinott, J., Peterman, A., Margolies, A., Moreira, V. (2014) Cash, Food, or Vouchers? Evidence from a Randomized Experiment in Northern Ecuador. Journal of Development Economics 107(C), 144-156.

Hoddinott, J., Skoufias, E. (2004) The Impact of PROGRESA on Food Consumption. Economic development and cultural change 53(1), 37-61.

Humphreys, M., Weinstein, J. (2007) Demobilization and reintegration. Journal of Conflict Resolution 51(4), 531-567.

Kaboski, J., Townsend, R. (2011) A Structural Evaluation of a Large-Scale Quasi-Experimental Microfinance Initiative. Econometrica 79(5), 1357-1406.

Kim, J., Alderman, H., Orazem, P. F. (1999) Can Private School Subsidies Increase Enrollment for the Poor? The Quetta Urban Fellowship Program. The World Bank Economic Review $13(3), 443-465$.

Kling, J. R., Liebman, J. B., Katz, L. F. (2007) Experimental analysis of neighborhood effects. Econometrica 75(1), 83-119.

Mastrobuoni, G., Weinberg, M. (2009) Heterogeneity in Intra-monthly Consumption Patterns, Self-control, and Savings at Retirement. American Economic Journal: Economic Policy 1(2), 163-189.

McKenzie, D. (2012) Beyond Baseline and Follow-up: The Case for more $\mathrm{T}$ in Experiments. Journal of Development Economics 99(2), 210-221.

Mel, S., McKenzie, D., Woodruff, C. M. (2008) Returns to Capital in Microenterprises: Evidence from a Field experiment. Quarterly Journal of Economics 123(4), 1329-1372.

Miguel, E., Kremer, M. (2004) Worms: Identifying Impacts on Education and Health in the Presence of Treatment Externalities. Econometrica 72(1), 159-217.

Muggah, R. (2009) Security and Post-Conflict Reconstruction. Dealing with fighters in the aftermath of war. Routledge, New-York, USA.

Ndayiziga, C., Nakimana, L., Birutegusa, B., Ntakirutimana, S., Nkeshimana, T. (2008) Défis à la Paix Durable: Autoportrait du Burundi. Centre d'Alerte et de Prévention des Conflits (Cenap) and Interpeace, Bujumbura, Burundi.

Ozdenoren, E., Salant, S. W., Silverman, D. (2012) Willpower and the Optimal Control of Visceral Urges. Journal of the European Economic Association 10(2), 342-368. 
Platteau, J.-P. (2000) Institutions, Social Norms, and Economic Development, vol 1. Routledge Press, Abingdon, UK.

Pugel, J. (2009) Measuring Reintegration in Liberia: Assessing the Gap between Outputs and Outcomes. In: Muggah, R. (ed) Security and Post-Conflict Reconstruction. Dealing with fighters in the aftermath of war., Routledge, New-York, USA.

Sadoulet, E., De Janvry, A., Davis, B. (2001) Cash Transfer Programs with Income Multipliers: PROCAMPO in Mexico. World development 29(6), 1043-1056.

Shapiro, J. (2005) Is there a Daily Discount Rate? Evidence from the Food Stamp Nutrition Cycle. Journal of public Economics 89(2), 303-325.

Stephens, M. (2006) Paycheque Receipt and the Timing of Consumption. The Economic Journal 116(513), 680-701.

Stephens Jr, M. (2003) "3rd of tha Month": Do Social Security Recipients Smooth Consumption Between Checks? American Economic Review 93(1), 406-422.

The World Bank Group (2004) Technical Annex for a proposed grant of SDR 22.2 million (US\$ 33 million equivalent) to Republic of Burundi for an emergency demobilization, reinsertion and reintegration program. Mimeo.

Udry, C. R. (1996) Gender, Agricultural Production, and the Theory of the Household. Journal of Political Economy 104(5), 1010-46.

Uvin, P. (2007) Ex-combatants in Burundi: Why they Joined, Why they Left, How they Fared. The International Bank for Reconstruction and Development / The World Bank, Washington, USA.

Vandeginste, S. (2009) Power-Sharing, Conflict and Transition in Burundi: Twenty Years of Trial and Error. Africa Spectrum 44(3), 63-86.

Verwimp, P., Bundervoet, T. (2009) Civil War and the Welfare of Extended Households: Evidence from Longitudinal Data from Burundi. HiCN Working Papers, no. 70.

Willems, R., Kleingeld, J., Leeuwen, M. (2010) Connecting Community Security and DDR : Experiences from Burundi. Peace, Security and Development Network, The Hague, The Netherlands.

Zoyem, J.-P., Diang'a, E., Wodon, Q. (2008) Mesures et determinants de l'insecurite alimentaire au burundi selon l'approche de l'apport calorifique. The African Statistical Journal 6, 38-45. 
Appendix A. Online appendix - Attrition and supplementary tables

Table S.1: Selective Attrition - Becketti et al (1988) method

\begin{tabular}{|c|c|c|c|c|c|}
\hline & $\begin{array}{l}\text { Total } \\
\text { cons. } \\
(1)\end{array}$ & $\begin{array}{c}\text { Cons. } \\
\text { expend. } \\
(2)\end{array}$ & $\begin{array}{c}\text { Cons. } \\
\text { stocks } \\
(3)\end{array}$ & $\begin{array}{c}\text { Nonfood } \\
\text { spending } \\
(4)\end{array}$ & $\begin{array}{c}\text { Tropical } \\
\text { Livestock } \\
(5)\end{array}$ \\
\hline \multirow[t]{2}{*}{ Traced Household } & 0.508 & 0.151 & 0.122 & 2.068 & 0.070 \\
\hline & $(0.521)$ & $(0.805)$ & $(1.142)$ & $(1.269)$ & $(0.079)$ \\
\hline \multirow[t]{2}{*}{$\mathrm{CNDD}+$ factions $\left(S_{i}^{C N D D+}\right)$} & -0.016 & 0.003 & $-0.044^{* *}$ & 0.012 & $-0.004^{* * *}$ \\
\hline & $(0.010)$ & $(0.012)$ & $(0.019)$ & $(0.024)$ & $(0.001)$ \\
\hline \multirow[t]{2}{*}{ CNDD + factions $\left(S_{i}^{C N D D+}\right) \times$ Traced } & 0.006 & -0.005 & 0.026 & -0.017 & 0.003 \\
\hline & $(0.010)$ & $(0.013)$ & $(0.018)$ & $(0.018)$ & $(0.002)$ \\
\hline \multirow[t]{2}{*}{ FNL factions $\left(S_{i}^{F N L}\right)$} & 0.004 & 0.015 & 0.004 & 0.010 & $0.005^{* *}$ \\
\hline & $(0.012)$ & $(0.009)$ & $(0.031)$ & $(0.024)$ & $(0.002)$ \\
\hline \multirow[t]{2}{*}{ FNL factions $\left(S_{i}^{F N L}\right) \times$ Traced } & 0.005 & 0.007 & -0.004 & 0.004 & -0.004 \\
\hline & $(0.009)$ & $(0.009)$ & $(0.026)$ & $(0.021)$ & $(0.003)$ \\
\hline \multirow[t]{2}{*}{ Violence } & -0.004 & 0.031 & -0.081 & 0.053 & 0.005 \\
\hline & $(0.034)$ & $(0.045)$ & $(0.080)$ & $(0.095)$ & $(0.006)$ \\
\hline \multirow[t]{2}{*}{ Violence $\times$ Traced } & -0.007 & -0.045 & 0.072 & 0.015 & -0.006 \\
\hline & $(0.037)$ & $(0.049)$ & $(0.078)$ & $(0.093)$ & $(0.008)$ \\
\hline \multirow[t]{2}{*}{ Sex Head } & $0.525^{*}$ & 0.125 & 0.631 & 1.058 & -0.010 \\
\hline & $(0.270)$ & $(0.394)$ & $(0.611)$ & $(0.716)$ & $(0.032)$ \\
\hline \multirow[t]{2}{*}{ Sex Head $\times$ Traced } & $-0.551^{*}$ & -0.128 & -0.408 & -1.021 & -0.005 \\
\hline & $(0.318)$ & $(0.469)$ & $(0.655)$ & $(0.734)$ & $(0.041)$ \\
\hline \multirow[t]{2}{*}{ Age Head } & -0.006 & $-0.016^{* *}$ & 0.004 & -0.009 & 0.000 \\
\hline & $(0.005)$ & $(0.007)$ & $(0.010)$ & $(0.008)$ & $(0.000)$ \\
\hline \multirow[t]{2}{*}{ Age Head $\times$ Traced } & 0.006 & $0.016^{* *}$ & -0.004 & 0.004 & 0.000 \\
\hline & $(0.005)$ & $(0.008)$ & $(0.010)$ & $(0.010)$ & $(0.001)$ \\
\hline \multirow[t]{2}{*}{ Married } & -0.335 & -0.122 & -0.318 & 0.131 & 0.043 \\
\hline & $(0.389)$ & $(0.325)$ & $(0.714)$ & (1.035) & $(0.029)$ \\
\hline \multirow[t]{2}{*}{ Married $\times$ Traced } & 0.326 & -0.088 & 0.576 & -0.034 & -0.029 \\
\hline & $(0.402)$ & $(0.354)$ & $(0.723)$ & (1.085) & $(0.048)$ \\
\hline \multirow[t]{2}{*}{ Divorced } & -0.191 & 0.404 & 0.155 & -1.109 & -0.009 \\
\hline & $(0.446)$ & $(0.437)$ & $(0.767)$ & $(0.939)$ & $(0.058)$ \\
\hline \multirow[t]{2}{*}{ Divorced $\times$ Traced } & 0.261 & -0.344 & -0.234 & 1.199 & -0.073 \\
\hline & $(0.418)$ & $(0.651)$ & $(0.981)$ & $(1.076)$ & $(0.067)$ \\
\hline \multirow[t]{2}{*}{ Widow } & 0.169 & 0.427 & -0.235 & 0.424 & -0.009 \\
\hline & $(0.417)$ & $(0.447)$ & $(0.790)$ & $(0.996)$ & $(0.041)$ \\
\hline \multirow[t]{2}{*}{ Widow $\times$ Traced } & -0.184 & -0.756 & 0.785 & -0.700 & -0.029 \\
\hline & $(0.427)$ & $(0.510)$ & $(0.811)$ & $(1.038)$ & $(0.056)$ \\
\hline \multirow[t]{2}{*}{ Primary School } & $0.361^{* *}$ & $0.923^{* * *}$ & 0.097 & $0.624^{* *}$ & 0.026 \\
\hline & $(0.161)$ & $(0.303)$ & $(0.346)$ & $(0.284)$ & $(0.023)$ \\
\hline Primary School $\times$ Traced & -0.141 & $-0.689^{* *}$ & 0.232 & -0.220 & -0.011 \\
\hline
\end{tabular}


Table S.1 - continued from previous page

\begin{tabular}{lccccc} 
& $(1)$ & $(2)$ & $(3)$ & $(4)$ & $(5)$ \\
\hline Secondary School & $(0.176)$ & $(0.313)$ & $(0.340)$ & $(0.273)$ & $(0.027)$ \\
& 0.132 & $0.506^{*}$ & -0.233 & 0.316 & 0.021 \\
Secondary School $\times$ Traced & $(0.147)$ & $(0.286)$ & $(0.330)$ & $(0.377)$ & $(0.023)$ \\
& 0.066 & -0.399 & 0.616 & -0.017 & 0.001 \\
Small business & $(0.208)$ & $(0.260)$ & $(0.409)$ & $(0.358)$ & $(0.039)$ \\
& 0.029 & 0.051 & 0.055 & $0.717^{*}$ & 0.047 \\
Small business $\times$ Traced & $(0.206)$ & $(0.248)$ & $(0.389)$ & $(0.393)$ & $(0.067)$ \\
& 0.048 & 0.010 & 0.004 & -0.379 & -0.039 \\
Construction & $(0.217)$ & $(0.257)$ & $(0.439)$ & $(0.467)$ & $(0.071)$ \\
& 0.012 & 0.131 & 0.354 & -0.088 & -0.017 \\
Construction $\times$ Traced & $(0.275)$ & $(0.371)$ & $(0.330)$ & $(0.576)$ & $(0.029)$ \\
& 0.181 & 0.062 & -0.468 & 0.032 & 0.027 \\
Public sector & $(0.295)$ & $(0.396)$ & $(0.362)$ & $(0.609)$ & $(0.032)$ \\
& 0.159 & 0.016 & 0.564 & $0.680^{* *}$ & 0.002 \\
Public sector $\times$ Traced & $(0.460)$ & $(0.515)$ & $(0.486)$ & $(0.338)$ & $(0.069)$ \\
Constant & 0.073 & 0.349 & -0.822 & -0.232 & 0.058 \\
& $(0.442)$ & $(0.513)$ & $(0.527)$ & $(0.466)$ & $(0.074)$ \\
Observations & $8.875^{* * *}$ & $8.603^{* * *}$ & $7.467^{* * *}$ & $6.956^{* * *}$ & 0.008 \\
$R^{2}$ & $(0.478)$ & $(0.687)$ & $(1.078)$ & $(1.281)$ & $(0.063)$ \\
\hline F-test Traced HH & 1178 & 1191 & 1105 & 1076 & 1195 \\
$p$-value F-test & 0.050 & 0.085 & 0.049 & 0.088 & 0.040 \\
F-test interactions variables & & & & & \\
$p$-value F-test & & & & \\
& 0.95 & 0.04 & 0.01 & 2.65 & 0.79 \\
\hline \hline
\end{tabular}

Notes: Selective attrition has been tested for the log of dependent variables in 2006. Consumption and spendings are per adult equivalent. We did not trace only one household which had a member working in the extractive sector so it is omitted. Sampling weights are accounted for. Clustered-robust standard errors are in parentheses. ${ }^{*} p<0.10,{ }^{* *} p<0.05,{ }^{* * *} p<0.01$ 
Table S.2: Selective Attrition - Fitzgerald et al (1998) method with Probit

Dependent variable: Probability to be traced in 2010

\begin{tabular}{|c|c|c|c|c|c|c|}
\hline & (1) & (2) & (3) & (4) & (5) & (6) \\
\hline \multirow[t]{2}{*}{ Log total consumption } & 0.005 & & & & & 0.103 \\
\hline & $(0.059)$ & & & & & $(0.202)$ \\
\hline \multirow[t]{2}{*}{ Log consumption expenditures } & & -0.033 & & & & -0.115 \\
\hline & & $(0.057)$ & & & & $(0.135)$ \\
\hline \multirow[t]{2}{*}{ Log consumption from stocks } & & & 0.069 & & & 0.042 \\
\hline & & & $(0.044)$ & & & $(0.093)$ \\
\hline \multirow[t]{2}{*}{ Log nonfood spending } & & & & 0.037 & & -0.008 \\
\hline & & & & $(0.044)$ & & $(0.051)$ \\
\hline \multirow[t]{2}{*}{ Log tropical livestock 6} & & & & & 0.500 & 0.384 \\
\hline & & & & & $(0.319)$ & $(0.338)$ \\
\hline \multirow{2}{*}{ CNDD+ factions $\left(S_{i}^{C N D D+}\right)$} & & & & & & $-0.018^{* *}$ \\
\hline & & & & & & $(0.008)$ \\
\hline \multirow{2}{*}{ FNL factions $\left(S_{i}^{F N L}\right)$} & & & & & & 0.011 \\
\hline & & & & & & $(0.010)$ \\
\hline \multirow[t]{2}{*}{ Violence } & & & & & & -0.020 \\
\hline & & & & & & $(0.043)$ \\
\hline \multirow[t]{2}{*}{ Sex Head } & & & & & & -0.143 \\
\hline & & & & & & $(0.196)$ \\
\hline \multirow[t]{2}{*}{ Age Head } & & & & & & 0.002 \\
\hline & & & & & & $(0.005)$ \\
\hline \multirow[t]{2}{*}{ Married } & & & & & & 0.479 \\
\hline & & & & & & $(0.332)$ \\
\hline \multirow[t]{2}{*}{ Divorced } & & & & & & -0.052 \\
\hline & & & & & & $(0.556)$ \\
\hline \multirow[t]{2}{*}{ Widow } & & & & & & 0.135 \\
\hline & & & & & & $(0.398)$ \\
\hline \multirow[t]{2}{*}{ Primary School } & & & & & & -0.099 \\
\hline & & & & & & $(0.125)$ \\
\hline \multirow[t]{2}{*}{ Secondary School } & & & & & & 0.078 \\
\hline & & & & & & $(0.161)$ \\
\hline \multirow[t]{2}{*}{ Small business } & & & & & & 0.231 \\
\hline & & & & & & $(0.216)$ \\
\hline \multirow[t]{2}{*}{ Construction } & & & & & & 0.098 \\
\hline & & & & & & $(0.230)$ \\
\hline \multirow[t]{2}{*}{ Extractive activity } & & & & & & 0.175 \\
\hline & & & & & & $(0.534)$ \\
\hline \multirow[t]{2}{*}{ Public sector } & & & & & & 0.240 \\
\hline & & & & & & $(0.305)$ \\
\hline \multirow[t]{2}{*}{ Constant } & $0.934^{*}$ & $1.276^{* * *}$ & 0.457 & 0.645 & $0.935^{* * *}$ & 0.507 \\
\hline & $(0.560)$ & $(0.485)$ & $(0.380)$ & $(0.400)$ & $(0.061)$ & $(0.832)$ \\
\hline Province FE & No & No & No & No & No & Yes \\
\hline Observations & 1227 & 1227 & 1123 & 1102 & 1232 & 1007 \\
\hline
\end{tabular}


Table S.3: Selective Attrition - Fitzgerald et al (1998) method with OLS

Dependent variable: Probability to be traced in 2010

\begin{tabular}{|c|c|c|c|c|c|c|}
\hline & $(1)$ & (2) & (3) & (4) & $(5)$ & (6) \\
\hline \multirow[t]{2}{*}{ Log total consumption } & 0.001 & & & & & -0.073 \\
\hline & $(0.015)$ & & & & & $(0.072)$ \\
\hline \multirow[t]{2}{*}{ Log consumption expenditures } & & -0.009 & & & & 0.006 \\
\hline & & $(0.014)$ & & & & $(0.057)$ \\
\hline \multirow[t]{2}{*}{ Log consumption from stocks } & & & 0.017 & & & 0.040 \\
\hline & & & $(0.011)$ & & & $(0.030)$ \\
\hline \multirow[t]{2}{*}{ Log nonfood spending } & & & & 0.010 & & -0.001 \\
\hline & & & & $(0.011)$ & & $(0.013)$ \\
\hline \multirow[t]{2}{*}{ Log tropical livestock units } & & & & & $0.113^{*}$ & 0.061 \\
\hline & & & & & $(0.059)$ & $(0.062)$ \\
\hline \multirow[t]{2}{*}{ CNDD+ factions $\left(S_{i}^{C N D D+}\right)$} & & & & & & $-0.005^{* *}$ \\
\hline & & & & & & $(0.002)$ \\
\hline \multirow[t]{2}{*}{ FNL factions $\left(S_{i}^{F N L}\right)$} & & & & & & 0.002 \\
\hline & & & & & & $(0.002)$ \\
\hline \multirow[t]{2}{*}{ Violence } & & & & & & -0.005 \\
\hline & & & & & & $(0.011)$ \\
\hline \multirow[t]{2}{*}{ Sex Head } & & & & & & -0.032 \\
\hline & & & & & & $(0.048)$ \\
\hline \multirow[t]{2}{*}{ Age Head } & & & & & & 0.000 \\
\hline & & & & & & $(0.001)$ \\
\hline \multirow[t]{2}{*}{ Married } & & & & & & 0.149 \\
\hline & & & & & & $(0.112)$ \\
\hline \multirow[t]{2}{*}{ Divorced } & & & & & & 0.010 \\
\hline & & & & & & $(0.186)$ \\
\hline \multirow[t]{2}{*}{ Widow } & & & & & & 0.071 \\
\hline & & & & & & $(0.123)$ \\
\hline \multirow[t]{2}{*}{ Primary School } & & & & & & -0.021 \\
\hline & & & & & & $(0.029)$ \\
\hline \multirow[t]{2}{*}{ Secondary School } & & & & & & 0.015 \\
\hline & & & & & & $(0.036)$ \\
\hline \multirow[t]{2}{*}{ Small business } & & & & & & 0.045 \\
\hline & & & & & & $(0.039)$ \\
\hline \multirow[t]{2}{*}{ Construction } & & & & & & 0.023 \\
\hline & & & & & & $(0.051)$ \\
\hline \multirow[t]{2}{*}{ Extractive activity } & & & & & & 0.049 \\
\hline & & & & & & $(0.103)$ \\
\hline \multirow[t]{2}{*}{ Public Sector } & & & & & & 0.053 \\
\hline & & & & & & $(0.058)$ \\
\hline \multirow[t]{2}{*}{ Constant } & $0.825^{* * *}$ & $0.912^{* * *}$ & $0.708^{* * *}$ & $0.749^{* * *}$ & $0.825^{* * *}$ & $0.737^{* * *}$ \\
\hline & $(0.142)$ & $(0.123)$ & $(0.098)$ & $(0.105)$ & $(0.015)$ & $(0.219)$ \\
\hline Province FE & No & No & No & No & No & Yes \\
\hline Observations & 1227 & 1227 & 1123 & 1102 & 1232 & 1007 \\
\hline$R^{2}$ & 0.000 & 0.001 & 0.003 & 0.001 & 0.004 & 0.030 \\
\hline
\end{tabular}

Notes: Authors' analysis based on data described in the text. The table reports OLS estimates. Selective attrition has been tested for the log of dependent variables in 2006. Consumption and spendings are per adult equivalent. Sampling weights are accounted for. Clustered-robust standard errors are in parentheses. $* p<0.10, * * p<0.05, * * * p<0.01$ 


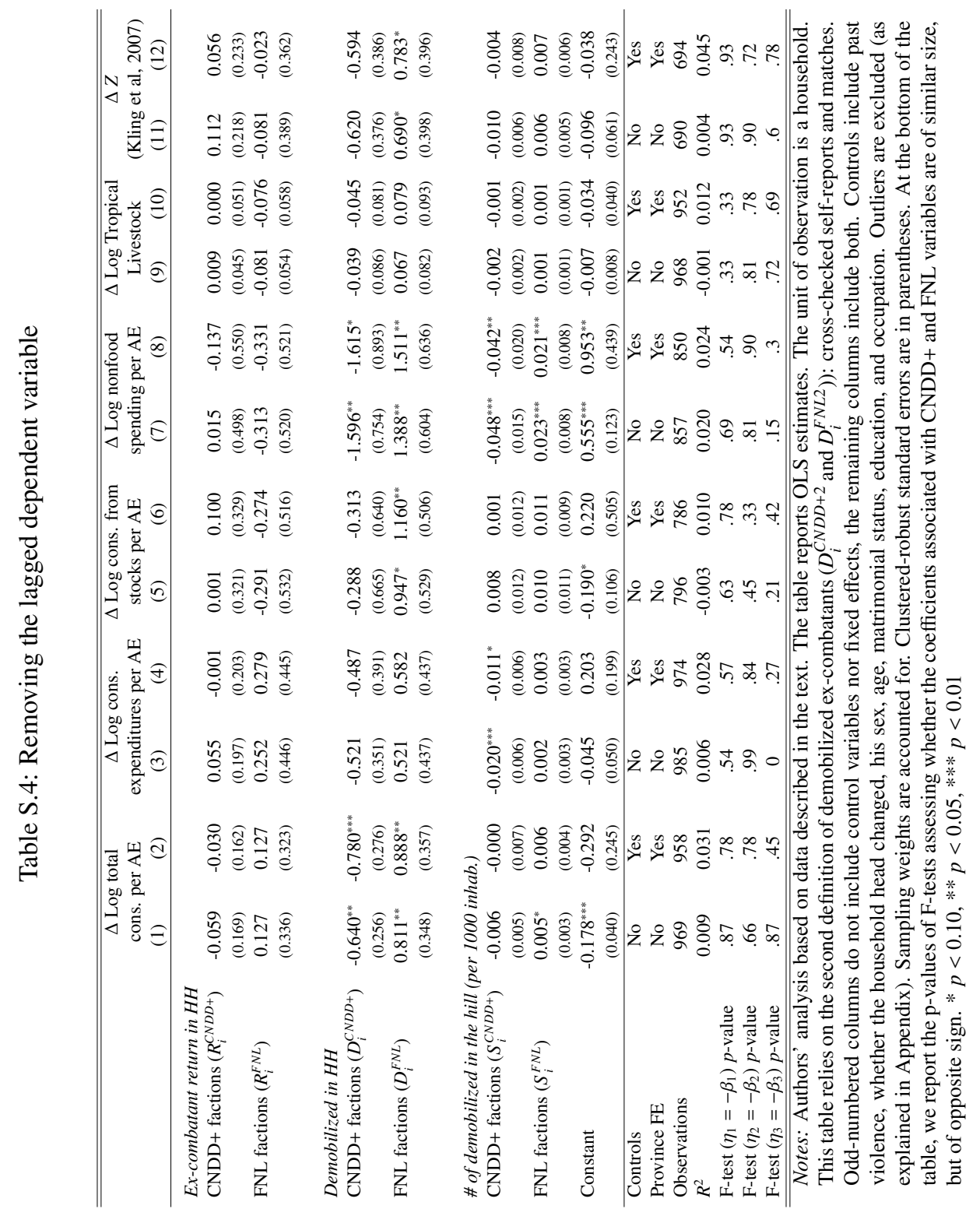


Table S.5(a) displays descriptive statistics of the dependent variables at baseline. There are no differences between households who did not receive the grants and civilians for all indicators (Test (2) and (3)) except for food consumption, which was higher than civilians. These differences are absent for the FNL in 2006. Comparing households which have received a grant to those who did not (Tests (4) and (5)), all indicators are similar except for consumption from stock among FNLs, which was particularly low. Apart in the consumption from stocks, there is no striking differences between factions according to tests (1), (4) and (5); nor within factions (Tests (6) and (7)) at baseline.

In 2006, there were not much differences in socio-demographic characteristics between the civilians and the households that did not receive the grants in terms of socio-demographic characteristics (Tests (2) and (3)); nor between returnees households (whether they benefited from the program or not) (Tests (6) and (7), Table $S .5(b)$ ). The latter is true for both groups (Tests (4) and (5)). Some proportions are too small to be compared. Since we control for those characteristics, the few differences will be accounted for.

Table $S .5(\mathrm{c})$ is a preview of results on to the direct impact of the program. The FNL households that did receive the grants are be better off than their CNDD peers when money is required (Test (5), consumption expenditures and nonfood spending). The average indicators for the households that did not receive the grants are not different than the civilians' means (Tests (2) and (3)). 
Table S.5: Descriptive statistics by demobilization status

(a) Dependent variables in 2006

\begin{tabular}{|c|c|c|c|c|c|c|c|c|c|c|c|c|}
\hline & \multirow{2}{*}{$\begin{array}{c}\text { Civilians } \\
\text { [A] }\end{array}$} & \multicolumn{2}{|c|}{ CNDD } & \multicolumn{2}{|c|}{ FNL } & \multicolumn{7}{|c|}{$p$-value joint tests } \\
\hline & & $\begin{array}{l}\text { Non-Demob. } \\
{[\mathrm{B}]}\end{array}$ & $\begin{array}{c}\text { Demob. } \\
{[\mathrm{C}]}\end{array}$ & $\begin{array}{l}\text { Non-Demob. } \\
{[\mathrm{D}]}\end{array}$ & $\begin{array}{c}\text { Demob. } \\
{[\mathrm{E}]}\end{array}$ & (1) & (2) & (3) & (4) & (5) & (6) & (7) \\
\hline Total Consumption & $\begin{array}{l}15973 \\
(471)\end{array}$ & 18375 & 21063 & 15514 & 10759 & 0.351 & 0.129 & 0.89 & 0.436 & 0.214 & 0.946 & 0.438 \\
\hline Consumption expenditure & $\begin{array}{l}8672 \\
(519)\end{array}$ & 12317 & 8581 & 9219 & 8495 & 0.292 & 0.032 & 0.818 & 0.299 & 0.519 & 0.101 & 0.736 \\
\hline Consumption from stocks & $\begin{array}{l}7141 \\
(390)\end{array}$ & 6058 & 12452 & 6296 & 2248 & 0 & 0.569 & 0.501 & 0.918 & 0.001 & 0.053 & 0.193 \\
\hline Nonfood spending & $\begin{array}{l}20051 \\
(2341)\end{array}$ & 41374 & 33905 & 22226 & 18239 & 0.32 & 0.293 & 0.781 & 0.364 & 0.847 & 0.466 & 0.704 \\
\hline TLU & $\begin{array}{c}0.113 \\
(0.008)\end{array}$ & 0.119 & 0.186 & 0.151 & 0 & 0.489 & 0.883 & 0.561 & 0.688 & 0.591 & 0.604 & 0.743 \\
\hline
\end{tabular}

(b) Socio-demographic characteristics in 2006

\begin{tabular}{|c|c|c|c|c|c|c|c|c|c|c|c|c|}
\hline & \multirow{2}{*}{$\begin{array}{c}\text { Civilians } \\
\text { [A] }\end{array}$} & \multicolumn{2}{|c|}{ CNDD } & \multicolumn{2}{|c|}{ FNL } & \multicolumn{7}{|c|}{$p$-value joint tests } \\
\hline & & $\begin{array}{c}\text { Non-Demob. } \\
{[B]}\end{array}$ & $\begin{array}{l}\text { Demob. } \\
{[\mathrm{C}]}\end{array}$ & $\begin{array}{c}\text { Non-Demob. } \\
{[\mathrm{D}]}\end{array}$ & $\begin{array}{c}\text { Demob. } \\
{[E]}\end{array}$ & (1) & (2) & (3) & (4) & (5) & (6) & (7) \\
\hline Age & $\begin{array}{l}42.3 \\
(0.7)\end{array}$ & 37.1 & 40.8 & 37.6 & 43.2 & 0.099 & 0.082 & 0.058 & 0.879 & 0.749 & 0.197 & 0.075 \\
\hline No schooling (\%) & $\begin{array}{c}0.35 \\
(0.02)\end{array}$ & 0.16 & 0.2 & 0.41 & 0.46 & 0.282 & 0.033 & 0.717 & 0.16 & 0.973 & 0.322 & 0.993 \\
\hline Primary schooling (\%) & $\begin{array}{c}0.39 \\
(0.02)\end{array}$ & 0.78 & 0.78 & 0.4 & 0.34 & 0.001 & 0 & 0.893 & 0.018 & 0.821 & 0.107 & 0.812 \\
\hline Secondary schooling (\%) & $\begin{array}{c}0.26 \\
(0.02)\end{array}$ & 0.06 & 0.01 & 0.19 & 0.2 & 0 & 0 & 0.441 & 0.232 & 0.761 & 0.158 & 0.699 \\
\hline Single $(\%)$ & $\begin{array}{c}0.02 \\
(0.01)\end{array}$ & 0 & -0.01 & 0 & 0.06 & 0.001 & 0 & 0 & 1 & 0.317 & 0.278 & 0.139 \\
\hline Married (\%) & $\begin{array}{c}0.81 \\
(0.03)\end{array}$ & 0.89 & 1.04 & 0.74 & 0.62 & 0 & 0.329 & 0.607 & 0.316 & 0.365 & 0.675 & 0.874 \\
\hline Divorced (\%) & $\begin{array}{c}0.02 \\
(0.01)\end{array}$ & 0 & 0 & 0 & 0 & 0.006 & 0.001 & 0.001 & & 0.354 & 0.002 & 0.001 \\
\hline Widow (\%) & $\begin{array}{c}0.15 \\
(0.02)\end{array}$ & 0.11 & -0.03 & 0.26 & 0.32 & 0 & 0.621 & 0.402 & 0.316 & 0.517 & 0.504 & 0.894 \\
\hline
\end{tabular}

(c) Dependent variables in 2010

\begin{tabular}{|c|c|c|c|c|c|c|c|c|c|c|c|c|}
\hline & \multirow{2}{*}{$\begin{array}{c}\text { Civilians } \\
\text { [A] }\end{array}$} & \multicolumn{2}{|c|}{ CNDD } & \multicolumn{2}{|c|}{ FNL } & \multicolumn{7}{|c|}{$p$-value joint tests } \\
\hline & & $\begin{array}{c}\text { Non-Demob. } \\
{[\mathrm{B}]}\end{array}$ & $\begin{array}{c}\text { Demob. } \\
{[\mathrm{C}]}\end{array}$ & $\begin{array}{c}\text { Non-Demob. } \\
\text { [D] }\end{array}$ & $\begin{array}{c}\text { Demob. } \\
\text { [E] }\end{array}$ & (1) & (2) & (3) & (4) & (5) & (6) & (7) \\
\hline Total Consumption & $\begin{array}{l}14008 \\
(485)\end{array}$ & 14765 & 11551 & 14666 & 18884 & 0.123 & 0.745 & 0.774 & 0.975 & 0.093 & 0.468 & 0.507 \\
\hline Consumption expenditure & $\begin{array}{l}7903 \\
(362)\end{array}$ & 11056 & 3600 & 9297 & 11882 & 0 & 0.165 & 0.441 & 0.552 & 0.003 & 0.026 & 0.757 \\
\hline Consumption from stocks & $\begin{array}{l}6164 \\
(386)\end{array}$ & 6560 & 7962 & 6156 & 7008 & 0.974 & 0.839 & 0.997 & 0.887 & 0.889 & 0.835 & 0.865 \\
\hline Nonfood spending & $\begin{array}{l}36118 \\
(2921)\end{array}$ & 60043 & 8309 & 23829 & 71957 & 0.002 & 0.229 & 0.052 & 0.085 & 0.027 & 0.073 & 0.08 \\
\hline TLU & $\begin{array}{c}0.096 \\
(0.007)\end{array}$ & 0.107 & 0.151 & 0.031 & 0 & 0.003 & 0.857 & 0 & 0.223 & 0.717 & 0.689 & 0.046 \\
\hline $\mathrm{N}$ & {$[920,978]$} & {$[20,22]$} & {$[16,17]$} & {$[6,7]$} & {$[10,11]$} & & & & & & & \\
\hline
\end{tabular}

Notes: Authors' analysis based on data described in the text. Clustered-robust standard errors are in parentheses. Outliers are excluded (as explained in Appendix B.1. Sampling weights are accounted for. Test (1) is a joint test that the means of the nondemobilized and demobilized of both groups are equal to the mean of the civilians $([A]=[B]=[C]=[D]=[E])$. Test $(2)$ compares the mean of the CNDD nondemobilized with the mean of civilians $([\mathrm{A}]=[\mathrm{B}])$. Test $(3)$ compares the mean of the FNL nondemobilized with the mean of civilians $([\mathrm{A}]=[\mathrm{D}])$. Test $(4)$ compares the means across nondemobilized $([\mathrm{B}]=[\mathrm{D}])$. Test $(5)$ compares the means across demobilized $([\mathrm{C}]=[\mathrm{E}])$. Test (6) compares the nondemobilized and the demobilized within the CNDD+ $([\mathrm{B}]=[\mathrm{C}])$, while test (7) compares the nondemobilized and the demobilized within the FNL $([\mathrm{D}]=[\mathrm{E}])$. The number of households in each group is in square brackets. It may vary as outliers or missing values are not taken into account when computing the means and standard deviations. 
In order to formally test whether the estimates are biased due by unobservables, we rely on the insights of Altonji et al (2005) and Bellows and Miguel (2009) to measure the relative influence of unobservables with respect to observables. The method requires estimating a regression with a restricted set of control variables and one with the full set of controls. Denoting $\hat{\alpha}_{R}$ the coefficient of interest measured in the former regression, and $\hat{\alpha}_{F}$ the coefficient measured in the latter regression, a large ratio $\frac{\hat{\alpha}_{F}}{\hat{\alpha}_{R}-\hat{\alpha}_{F}}$ indicates that the results cannot be plausibly explained entirely away by unobservables. The ratio is negative when the coefficient of interest is magnified with control variables, suggesting that controlling for unobservables would increase the magnitude and the significance of the coefficient. A ratio between 0 and 1 indicates that unobservables could have a large impact on the coefficient of interest. We consider two models: one without any control and one with the lagged dependent variable. Out of the 30 ratios presented in Table $\mathrm{S}$ 6(a) the only ones that are positive and less than one correspond to coefficients that are not significantly different from zero. Unobservables are therefore unlikely to drive our results. 
Table S.6: Using Selection on Observables to Assess the Bias from Unobservables

(a) CNDD

\begin{tabular}{llccc}
\hline \hline Dependent variable & Set of controls & $R_{i}^{C N D D+}$ & $D_{i}^{C N D D+}$ & $S_{i}^{C N D D+}$ \\
& & $(1)$ & $(2)$ & $(3)$ \\
\hline Total Consumption & No control & -0.37 & 9.76 & -1.21 \\
& Lag & 2.04 & -19.12 & 4.96 \\
Consumption expenditures & No control & -2.27 & -3.99 & -2.10 \\
& Lag & 2.08 & 12.50 & -11.19 \\
Consumption from stocks & No control & -0.88 & 0.53 & -1.03 \\
& Lag & -0.75 & -11.31 & 4.57 \\
\multirow{3}{*}{ Nonfood spending } & No control & -1.13 & 62.60 & -12.58 \\
\multirow{3}{*}{ TLU } & Lag & 0.98 & 14.39 & -21.85 \\
& No control & -3.58 & 0.15 & -1.63 \\
& Lag & 233.01 & -0.24 & 23.18 \\
\hline
\end{tabular}

(b) FNL

\begin{tabular}{llccc}
\hline \hline \multirow{2}{*}{ Dependent variable } & Set of controls & $R_{i}^{F N L}$ & $D_{i}^{F N L}$ & $S_{i}^{F N L}$ \\
& & $(1)$ & $(2)$ & $(3)$ \\
\hline Total Consumption & No control & 1.49 & 2.26 & -1.98 \\
& Lag & 6.35 & 35.00 & 9.95 \\
Consumption expenditures & No control & -10.06 & 2.29 & -1.15 \\
& Lag & -42.94 & 10.53 & 43.23 \\
Consumption from stocks & No control & -2.77 & 6.96 & -6.22 \\
& Lag & -8.11 & -6.28 & 16.79 \\
\multirow{4}{*}{ Nonfood spending } & No control & -23.82 & 29.99 & -4.00 \\
\multirow{2}{*}{ TLU } & Lag & -16.11 & 33.16 & 1538.95 \\
& No control & 3.55 & -4.82 & -2.41 \\
& Lag & 22.13 & -12.45 & -60.60 \\
\hline
\end{tabular}

Notes: Authors' analysis based on data described in the text. Each cell of the table reports ratios based on the coefficient corresponding to the respective column: column (1) is the ratio for returnees, column (2) for demobilized and column (3) for the spillovers. There are two lines per outcomes. The first is the restricted model without any control, and the second is a regression that includes the lagged dependent variable. For each outcome, each regression is based on the same sample size and includes province fixed effects. Denote $\hat{\alpha}_{R}$ the coefficients on the demobilization variables $(R, D$ and $S)$ when the model is restricted; and $\hat{\alpha}_{F}$ when the regression the full set of controls. The reported ratio is calculated as: $\frac{\hat{\alpha}_{F}}{\hat{\alpha}_{R}-\hat{\alpha}_{F}}$. Negative ratios reflect higher coefficient estimates when the full set is included relative to the restricted model, hence decreasing the relative role of unobservables in driving the effect. 


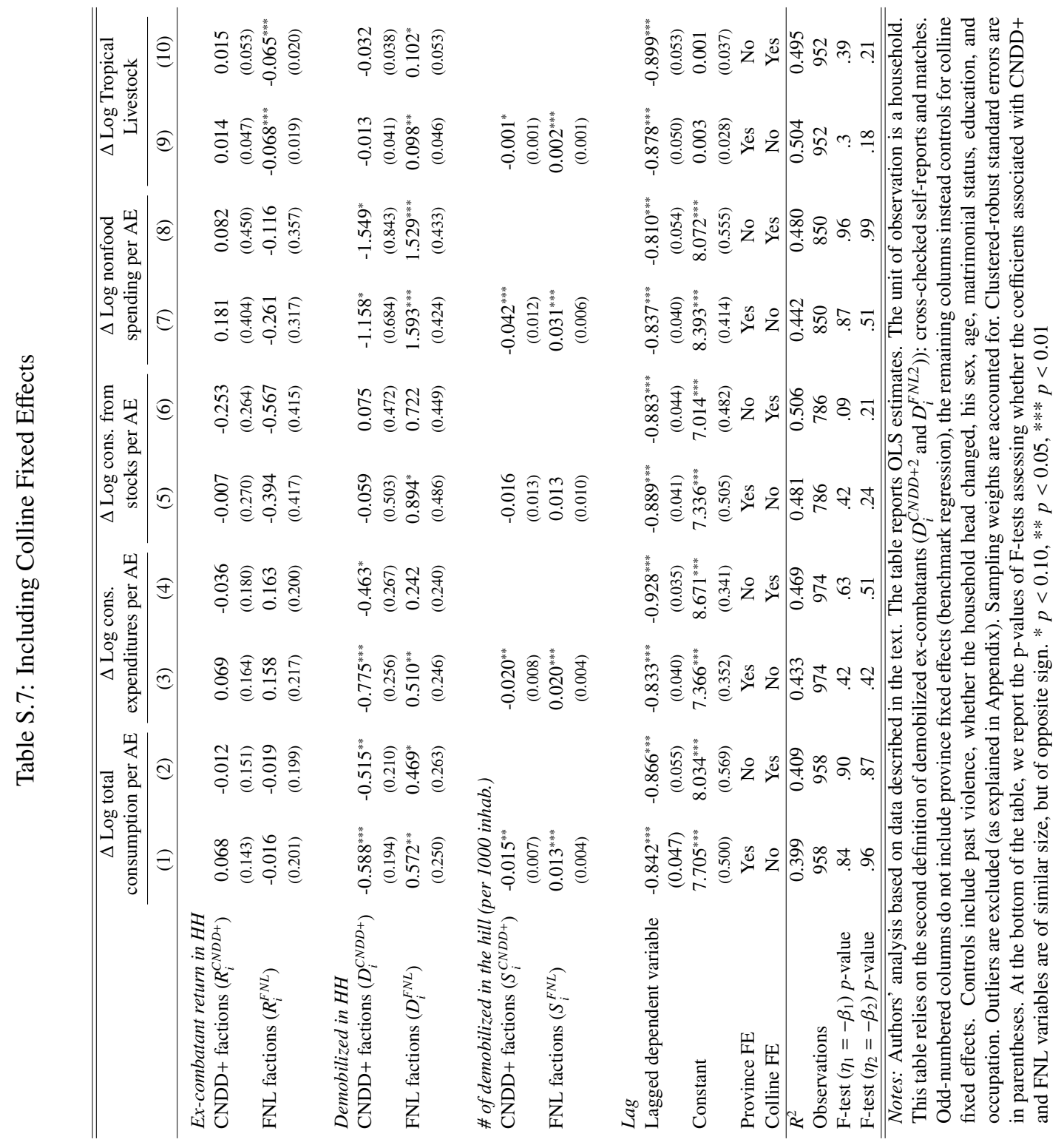




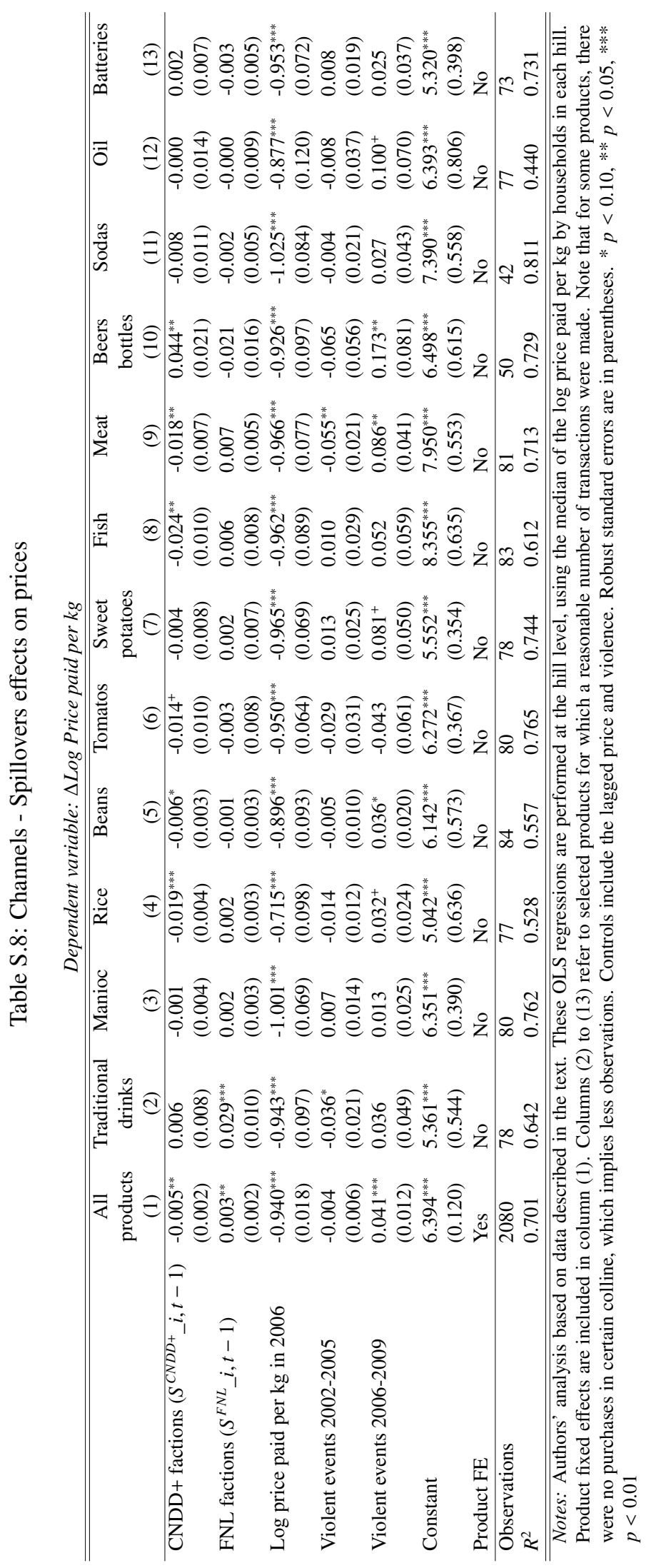


Table S.9: Channels - Proportion of ex-combatant households owning a shop

\begin{tabular}{lccc}
\hline \hline & \multicolumn{3}{c}{ Shop keepers } \\
& 2006 & 2010 & p-value \\
\hline CNDD+ & 0.558 & 0.307 & 0.292 \\
& $(0.287)$ & & \\
FNL & 0.12 & 0.448 & 0.126 \\
& $(0.126)$ & & \\
\hline
\end{tabular}

Notes: Authors' analysis based on data described in the text. Clustered-robust standard errors are in parentheses. Outliers are excluded (as explained in appendix). Sampling weights are accounted for. For household ex-combatants belonging to each group, the $p$-value corresponds to a test of equality of means of the share of kiosk owners between both surveys.

\section{Appendix B. Online Appendix - The Construction of Variables of Interest}

\section{Appendix B.1. The Construction of Consumption Aggregates}

In this appendix, we describe how we cleaned the data and constructed the relevant consumption aggregates for our analysis. First, we introduce the construction of the reference price vector and the local price vectors associated with each household. Second, we explain in detail how we corrected typing mistakes, how we treated missing and vague information, and how we dealt with outliers. Finally, we describe the construction of our main consumption measure which is a consumption aggregate per adult equivalent calculated using constant prices.

\section{Appendix B.1.1. Prices}

Prices faced by households are crucial in each stage of our analysis. First, in the data cleaning process, prices are an important to fill missing information as well as to detect and correct outliers. Second, in the construction of consumption aggregates, prices are used to make consumption data comparable across space and time. Following Deaton and Zaidi (2002), the harmonization of consumption data is done by scaling consumption values by a Paasche index of prices. Finally, finding a price increase in primary units where demobilized ex-combatants are numerous would corroborate the hypothesis that positive spillovers of the DDR program are due to a local economy effect.

We distinguish two sets of prices. On the one hand, the reference price matrix, denoted $p^{0}$, is a $47 \times 1$ vector such that each line is a reference price for one of our 47 consumption products. This matrix is common for all households and both periods of time. We used the 2010 panel survey as the reference year. For each one of the 47 products, the reference price was computed as follows. First, the most widely used unit of measurement was selected by considering the 
entire sample. In this process, we excluded vague ${ }^{30}$ and wrong ${ }^{31}$ units of measurement whose conversion into kilos is ambiguous. Second, the median price per unit was computed for this most used unit, and converted into kilos.

On the other hand, hill prices faced by each household are denoted $p^{h}$. These $47 \times 1$ vectors are different for each one of the 85 hills and for each periods of time. These local prices were computed as follows. Our survey distinguishes four levels of administrative subdivision: the whole survey area is divided into three provinces, 22 municipalities and 85 hills. For each hill and for each one of the 47 consumption products, the most used measurement unit was selected (still by excluding vague and wrong units of measurement). If this unit was used 10 times or more at the hill level, we computed the median price per unit, further converted into a median price per kilo. Conversely, if the most used unit was reported less than 10 times at the hill level, we followed the same procedure but at the municipality level. Again, if the most used unit at the municipality level was reported less than 10 times, the procedure was adapted at the province level. If less than 10 households reported a similar unit at the province level, then the procedure was done for the whole sample, even if no unit was used more than 10 times.

\section{Appendix B.1.2. Correction of Errors and Outliers}

In the correction process, we distinguished three types of manipulations: the correction of mistakes, the completion of missing data, and the treatment of outliers. First, we reviewed the data manually in order to find and correct recurrent typing mistakes such as the double entry of a number or the inversion between the code of the unit and the quantity. For few ambiguous cases, we replaced the suspicious information with a missing value.

Second, missing information was extrapolated in two cases. On the one side, if the amount spent for one consumption good was available and if the quantity or the unit (or both) were missing, the quantity consumed per kilo was calculated by dividing the amount spent by the local price per kilo $p^{h}$. If both the quantity and the measurement unit were reported but the amount paid was missing, this amount was imputed by multiplying the quantity consumed by the local price $p^{h}$ expressed in the same unit. All other cases were considered to be zero.

Finally, we looked for outliers. In order to identify the outlying observations, we computed the price paid per kilo for each household and each product by dividing the amount paid by the quantity consumed previously converted into kilos. By denoting Q1, Q2 and Q3 the first quartile, the median and the third quartile respectively, we define an outlier as an observation

\footnotetext{
${ }^{30}$ For example a basket, a pile or a pan.

${ }^{31}$ For example, a stere of meat or a liter of batteries.
} 
whose price paid per kilo lies outside the following fences. ${ }^{32}$

$$
\left[Q_{1}-k\left(Q_{2}-Q_{1}\right) ; Q_{3}+k\left(Q_{3}-Q_{2}\right)\right] \text { with } k=3 \text {. }
$$

For such observations, we then identified whether the amount paid or the quantity consumed was responsible for this extreme deviation from the median. On the one hand, if the amount paid was identified as extreme, it was replaced by multiplying the quantity consumed by the local price. On the other hand, if the quantity consumed was identified as the outlier, then the quantity consumed was replaced by the amount paid divided by the local price per kilo.

\section{Appendix B.1.3. Construction of consumption aggregates}

In order to construct consumption aggregates and to render these comparable between households in the two surveys, we constructed for each household what Deaton and Zaidi (2002) call a money metric utility. This consumption measure, denoted $u^{h}$, corresponds to the minimum cost for reaching a certain level of utility. Following Deaton and Zaidi (2002), the money metric utility $u^{h}$ can be approximated by the inner product of reference prices $p^{0}$ and the quantity consumed $q^{h}$, or equivalently, by adding up all the household's expenditures and dividing by a Paasche index of prices $P_{P}^{h}$ :

$$
u_{m}^{h} \approx p^{0} \cdot q^{h}=\frac{x^{h}}{P_{P}^{h}} \text { with } P_{P}^{h}=\frac{p^{h} \cdot q^{h}}{p^{0} \cdot q^{h}} .
$$

In order to construct this consumption indicator, we proceeded in three steps. First, we computed household's total expenditures by adding up food expenses to the value of selfconsumption and gifts. For each good, our questionnaire asked the quantity consumed and the quantity received as a gift, but not an estimate of their value. Hence, the value of consumption and gifts were calculated by multiplying the quantity converted into kilos by its local price.

In the second step, we built the Paasche index $P_{P}^{h}$ whose goal is to deflate household expenditures through the use of reference prices, therefore allowing comparisons across space and time. In order to construct the Paasche index, we used the following approximation (Deaton and Zaidi, 2002):

$$
\ln P_{P}^{h} \approx \sum w_{k}^{h} \ln \left(\frac{p_{k}^{h}}{p_{k}^{0}}\right),
$$

where $w_{k}^{h}$ is the share of household $h$ 's budget devoted to good $k$.

\footnotetext{
${ }^{32}$ Hubert, M., Vandervieren, E., 2008. An adjusted boxplot for skewed distributions. Computational statistics \& data analysis 52 (12), 5186âĂŞ5201.
} 
In the third step, the money metric utility at the household level is calculated by dividing household's total expenditures by the Paasche index. In order to obtain a measure of individual purchases, the household money metric utility has to be adjusted by taking into account household size. If each household member would consume an equal share of the household total expenditures, we could think about dividing consumption by household size. There are however differences between adults and children consumption. We should also correct for economies of scale inside households, arising from the distinction between private consumption (such as food consumption), and public good enjoyment (such as housing expenditures). Still following Deaton and Zaidi (2002), we computed different equivalence scales, which will be confronted against each other for robustness checks.

Adult equivalents are calculated according to the following formula:

$$
A E=[(1+\beta(A-1))+\alpha K]^{\theta},
$$

where $\mathrm{A}$ is the number of adults and $\mathrm{K}$ the number of children in the household. The parameter $\alpha$ is the cost of a child relative to that of an adult. It is assumed to be low in developing countries because expenditures are mainly associated with food consumption. The parameters $\beta$ and $\theta$ both account for economies of scale in household expenditures. On the one side, the parameter $\beta$ assigns a weight to all adults but one, which is weighted as 1 . On the other side, $\theta$ measures the elasticity of adult equivalents with respect to effective household size. As suggested in Deaton and Zaidi (2002), we use the following benchmark values for the parameters: $\alpha=0.3, \beta=1$ and $\theta=0.9$. The final money metric utility per adult equivalent used in our main empirical analysis is simply equal to the household money metric utility divided by the number of adult equivalents. 